\title{
APOBEC3B expression generates an immunogenic model of Kras mutant lung cancer
}

Sophie de Carné Trécesson ${ }^{1,14}$, Jesse Boumelha'1,14, Emily K. Law ${ }^{8-11,14}$, Pablo

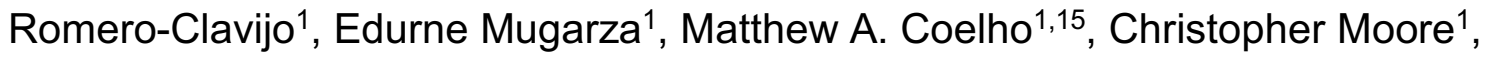
Sareena Rana ${ }^{1,5}$, Deborah R. Caswell ${ }^{3}$, Miguel Murillo ${ }^{1,5}$, David C. Hancock ${ }^{1}$,

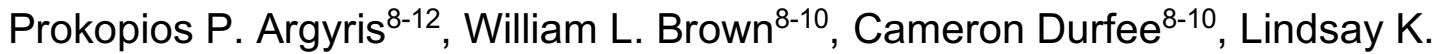
Larson $^{8-10}$, Rachel I. Vogel ${ }^{9,13}$, Alejandro Suárez-Bonnet ${ }^{4,7}$, Simon L. Priestnall ${ }^{4,7}$, Philip East ${ }^{2}$, Sarah J. Ross ${ }^{6}$, Miriam Molina-Arcas ${ }^{1}$, Charles Swanton ${ }^{3}$, Reuben Harris $^{8-11,16}$, Julian Downward ${ }^{1,5,16}$

${ }^{1}$ Oncogene Biology Laboratory, ${ }^{2}$ Bioinformatics and Biostatistics, ${ }^{3}$ Translational Cancer Therapeutics Laboratory and ${ }^{4}$ Experimental Histopathology,

Francis Crick Institute, 1 Midland Road, London NW1 1AT, UK

${ }^{5}$ Lung Cancer Group, Division of Molecular Pathology, Institute of Cancer Research, 237 Fulham Road, London SW3 6JB, UK.

${ }^{6}$ AstraZeneca Oncology R\&D, Cambridge CB4 OWG, UK

${ }^{7}$ Department of Pathobiology and Population Sciences, Royal Veterinary College, Hatfield, AL9 7TA, UK.

${ }^{8}$ Department of Biochemistry, Molecular Biology and Biophysics, University of Minnesota, Minneapolis, MN, USA, 55455

${ }^{9}$ Masonic Cancer Center, University of Minnesota, Minneapolis, MN, USA, 55455

${ }^{10}$ Institute for Molecular Virology, University of Minnesota, Minneapolis, MN, USA, 55455

${ }^{11}$ Howard Hughes Medical Institute, University of Minnesota, Minneapolis, MN, USA, 55455

${ }^{12}$ Division of Oral and Maxillofacial Pathology, School of Dentistry, University of Minnesota, Minneapolis, MN, USA, 55455

${ }^{13}$ Department of Obstetrics, Gynecology, and Women's Health, University of Minnesota, Minneapolis, MN, USA, 55455

14 These authors contributed equally

15 Present address: Sanger Institute, Hinxton CB10 1RQ, UK

${ }^{16}$ Correspondence: julian.downward@crick.ac.uk, rsh@umn.edu 


\section{ABSTRACT}

Mutations in oncogenes such as KRAS and EGFR cause a high proportion of lung cancers. Drugs targeting these proteins cause tumour regression but ultimately fail to cure these cancers, leading to intense interest in how best to combine them with other treatments, such as immunotherapies. However, preclinical systems for studying the interaction of lung tumours with the host immune system are inadequate, in part due to the low tumour mutational burden in genetically engineered mouse models. Here we set out to develop mouse models of mutant Kras-driven lung cancer with an elevated tumour mutational burden by expressing the human DNA cytosine deaminase, APOBEC3B, to mimic the mutational signature seen in human lung cancer. This causes an increase in mutational burden in Kras mutant and p53 deleted (KP) tumours and in carcinogen-induced tumours, but these mutations are sub-clonal and do not lead to sensitivity of the autochthonous tumours to immune interventions. However, when clonal cell lines are derived from these tumours they provide an immunogenic syngeneic transplantation lung cancer model that is sensitive to immunotherapy. The ability of a KRAS-G12C inhibitor to cause regression of these tumours is markedly potentiated by the adaptive immune system, providing an opportunity for the study of combinations of targeted and immunotherapies in immune-hot lung cancer. 
bioRxiv preprint doi: https://doi.org/10.1101/2020.12.22.423126; this version posted December 22, 2020. The copyright holder for this preprint (which was not certified by peer review) is the author/funder, who has granted bioRxiv a license to display the preprint in perpetuity. It is made available under aCC-BY 4.0 International license.

de Carné, Boumelha, Law et al.

22 December 2020

\section{INTRODUCTION}

Non-small cell lung cancer (NSCLC) is the leading cause of cancer-related deaths worldwide ${ }^{1}$. With less than $20 \%$ of NSCLC patients surviving more than 5 years $^{2}$, there is a pressing need for novel therapeutic strategies. Oncogenic mutations in KRAS, a member of the RAS family of small GTPases, occur in $20-30 \%$ of patients with NSCLC $^{3}$ and drive tumour development. Despite much effort, targeted therapies that aim to directly inhibit signalling pathways downstream of KRAS have shown limited success in the clinic for NSCLC patients ${ }^{4}$. However, the recent emergence of immune checkpoint blockade (anti-PD-1 and anti-CTLA-4), which can reverse tumour-driven immune suppression and unleash powerful anti-tumour immune responses, has transformed the treatment of NSCLC, achieving durable responses in some patients ${ }^{5,6}$. Unfortunately, as seen in other tumour types, only a subset of patients respond to immune checkpoint blockade (ICB).

It has therefore become critical to further elucidate the molecular determinants that underpin the interaction between the tumour and the immune system. Increasing evidence suggests that tumour-cell-intrinsic oncogenic signalling, including KRAS signalling ${ }^{7}$, can hamper anti-tumour immune responses and there is considerable interest in using targeted therapies to broaden the response to ICB. The recent development of KRAS-G12C inhibitors, which specifically target the most common mutant form of the protein in lung cancer, have shown that inhibiting KRAS-signalling in tumour cells promotes anti-tumour immune responses and synergises with anti-PD1 therapy in an immune competent model of colorectal cancer ${ }^{8}$.

Identifying rational therapeutic approaches to extend the clinical benefits of current ICBs in NSCLC requires the use of preclinical models that recapitulate the interactions between tumour cells and the immune system, which is not possible in conventional xenograft models lacking a functional immune system. Genetically engineered mouse models (GEMMs) have been extensively used to gain mechanistic insights into the biology of KRAS-mutant lung cancer and to assess the efficacy of novel therapeutics. Such models recapitulate key aspects of the human disease in an immune-competent setting, however, they fail to elicit strong anti-tumour immune responses ${ }^{9,10}$ and therefore have limited use for studying tumour-immune interactions. Genetically engineered mouse cancer models usually feature a small number of introduced strong driver mutations, sufficient for tumourigenesis, and acquire few additional mutations. 
Tumours arising from these models therefore have a low tumour mutational burden (TMB) compared to their human counterparts ${ }^{11}$, limiting the presentation of neoantigens to the adaptive immune system. This problem has been overcome by the forced expression of strong antigens, such as ovalbumin ${ }^{10,12,13}$, but it is unclear whether the strong anti-tumour immune responses elicited by such foreign antigens reflect those in human cancers which occur towards less potent neoantigens.

To address this issue we generated a novel GEMM of lung adenocarcinoma using the Kras ${ }^{\mathrm{LSL}-\mathrm{G} 12 \mathrm{D} /+} ; \mathrm{p} 53^{\mathrm{flfl} / \mathrm{I}}(\mathrm{KP})$ model with the added expression of human APOBEC3B, a member of the APOBEC family of single-stranded DNA deaminase enzymes, which is responsible for inducing mutations in a range of cancers ${ }^{14}$. While we found tumours arising in this model to be poorly immunogenic, by establishing clonal cell lines from these tumours we were able to generate an immunogenic transplantable model, KPAR1.3, which triggers anti-tumour immune responses and partially responds to ICB. In order to use this model to explore the immune-modulatory effects of KRAS$\mathrm{G} 12 \mathrm{C}$ inhibitors, we converted the KRAS ${ }^{\mathrm{G} 12 \mathrm{D}}$ alleles into KRAS ${ }^{\mathrm{G} 12 \mathrm{C}}$. KPAR1.3 ${ }^{\mathrm{G} 12 \mathrm{C}}$ cells were sensitive to the KRAS-G12C inhibitor, AZ-2087, both in vitro and in vivo. Furthermore, the response in vivo was greater in immune-competent hosts compared to immune-deficient mice, highlighting the importance of adaptive immunity in the response to KRAS-G12C inhibition. 
bioRxiv preprint doi: https://doi.org/10.1101/2020.12.22.423126; this version posted December 22, 2020. The copyright holder for this preprint (which was not certified by peer review) is the author/funder, who has granted bioRxiv a license to display the preprint in perpetuity. It is made available under aCC-BY 4.0 International license.

de Carné, Boumelha, Law et al.

22 December 2020

\section{RESULTS}

\section{Autochthonous KP lung tumours do not engage with the adaptive immune system}

The introduction of adenovirus expressing Cre recombinase (AdCre) into the lungs of $\mathrm{KP}$ mice leads to expression of oncogenic $\mathrm{Kras}^{\mathrm{G} 12 \mathrm{D}}$ and deletion of p53 in lung epithelial cells, resulting in the induction of lung adenocarcinoma ${ }^{15}$. To assess the immunogenicity of lung tumours arising in KP mice, we crossed them onto a Rag $2^{-/-}$ background, which lack mature $\mathrm{T}$ and $\mathrm{B}$ cells, and monitored tumour growth by microcomputed tomography (micro-CT) imaging. Adaptive immunity was unable to constrain the growth of KP tumours as they grew at similar rates in immune-competent $\left(\right.$ Rag2 $\left.^{+-}\right)$and immune-deficient $\left(\right.$Rag2 $\left.^{--}\right)$mice (Fig. 1A). Furthermore, immunohistochemistry staining revealed that tumours arising in immune-competent hosts lacked $\mathrm{T}$ cell infiltration (Fig. 1B). To assess whether an adaptive immune response could be generated against KP tumours, we treated tumour-bearing mice with a combination of anti-PD-L1 and anti-CTLA-4 (Fig. 1C). This combination therapy failed to delay tumour growth (Fig. 1D, E) and did not lead to an increase in the survival of tumour-bearing mice (Fig. 1F). It has previously been shown that MEK inhibition enhances anti-tumour immunity and synergises with anti-PD-L1 in Kras-mutant CT26 colorectal tumours $^{16}$. However, we found that the combination of anti-PD-L1 and trametinib failed to control KP tumour growth compared to trametinib alone (Supplementary Fig. 1A, B, C). These data suggest that autochthonous KP tumours were unable to be recognised by the adaptive immune system.

\section{Human APOBEC3B does not induce immunogenicity in the KP model}

In comparison with their human counterpart, KP lung tumours exhibit very few mutations which are necessary to generate neoantigens that make tumour cells visible to the immune system ${ }^{11}$. APOBEC3B is a single-stranded DNA cytosine deaminase that induces $C>T / G$ substitutions in several solid cancers ${ }^{14,17,18}$ and has been associated with intratumoural heterogeneity in lung adenocarcinoma ${ }^{19,20}$. We found that the expression of genes carrying non-synonymous APOBEC mutations were higher than those containing other types of mutations in LUAD samples from The Cancer Genome Atlas (TCGA) (Fig. 2A). Moreover, the mutational rate of nonsynonymous APOBEC mutations was lower in comparison with other types of mutation, suggesting that non-synonymous mutations generated by APOBEC could 
bioRxiv preprint doi: https://doi.org/10.1101/2020.12.22.423126; this version posted December 22, 2020. The copyright holder for this preprint (which was not certified by peer review) is the author/funder, who has granted bioRxiv a license to display the preprint in perpetuity. It is made available under aCC-BY 4.0 International license.

de Carné, Boumelha, Law et al.

22 December 2020

be subject to immune selection pressure and eliminated (Supplementary Fig.3A). We therefore decided to express human APOBEC3B in the KP model to increase the frequency of mutations in these tumours in the hope of increasing their visibility to the immune system. We inserted a human $A P O B E C 3 B$ minigene $(A 3 B i)$ in the Rosa26 locus under the control of a lox-STOP-lox cassette so that its expression is inducible upon exposure of cells to Cre recombinase (Supplementary Fig. 2A-J). A3Bi expression alone did not induce tumours and did not decrease the lifespan of the mice (Supplementary Fig. 2K-M). We crossed the mice with $\mathrm{KP}$ or $\mathrm{KP} ;$ Rag $^{1 /-}$ mice to generate Kras ${ }^{\mathrm{G} 12 \mathrm{D} /+} ; \operatorname{Trp}^{\mathrm{fl} / \mathrm{fl} ;} ; \operatorname{Rosa}^{\mathrm{A3Bi}} \quad$ (KPA) and

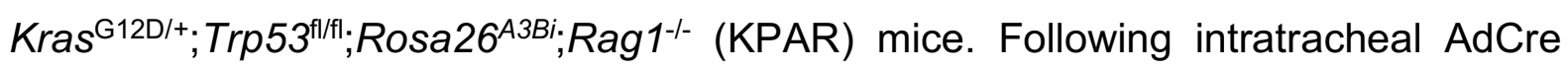
delivery, $\mathrm{A} 3 \mathrm{Bi}$ is expressed in the same cells as those that undergo Kras $^{\mathrm{G} 12 \mathrm{D}}$ expression and Trp53 deletion. As expected, we observed A3Bi protein expression in the nucleus of the tumour cells (Fig. $2 B$ ) and detected expression of its mRNA in most KPA and KPAR tumours (Fig. 2C).

To assess whether $\mathrm{A} 3 \mathrm{Bi}$ promoted immunogenicity in the $\mathrm{KP}$ tumours, we evaluated tumour growth by micro-CT imaging in immune-competent KPA and immune-deficient KPAR mice (Supplementary Fig. 3B). We observed no differences in tumour number or tumour size in KPAR mice compared with KPA mice (Fig. 2D, E). We treated KP and KPA tumour-bearing mice with anti-PD-1 and anti-CTLA-4 and observed no differences between the two groups (Fig. 2F). These results suggest that $\mathrm{A} 3 \mathrm{Bi}$ expression is not sufficient to promote immunogenicity in KP tumours.

Consistent with this finding, we did not observe $\mathrm{CD}^{+}$or $\mathrm{CD}^{+} \mathrm{T}$ cells in these tumours by immunohistochemistry (Fig. 2G). Moreover, we observed cytotoxic T cell and NK cell markers (Cd8b1 and Ncr1, respectively) in the adjacent lung tissue, but not in the tumours, suggesting that these cells are excluded from the tumour bed (Fig. $2 \mathrm{H}$, and Supplementary Fig. $3 \mathrm{C}$ ). We then performed whole-exome sequencing (WES) of KP and KPA tumours to verify whether A3Bi increased SNVs in the tumours. We found that the total number of exonic SNVs was moderately increased in A3Biexpressing tumours (Fig. 2l).

Altogether, these findings suggest that $\mathrm{A} 3 \mathrm{Bi}$ expression in the $\mathrm{KP}$ model of lung adenocarcinoma did not produce sufficient pro-immunogenic mutations to elicit an adaptive immune response. This may be in part because any potential neoantigens were subclonal and therefore not shared by all tumour cells, or alternatively due to insufficiently high levels of mutations induced in this system. 
bioRxiv preprint doi: https://doi.org/10.1101/2020.12.22.423126; this version posted December 22, 2020. The copyright holder for this preprint (which was not certified by peer review) is the author/funder, who has granted bioRxiv a license to display the preprint in perpetuity. It is made available under aCC-BY 4.0 International license.

de Carné, Boumelha, Law et al.

22 December 2020

\section{APOBEC3B increases subclonal mutations in urethane-induced tumours and does not promote immunogenicity}

Murine KP tumours develop extremely rapidly, inducing a life-threatening tumour burden in about 14 to 18 weeks. We reasoned that the aggressive nature of the KP model did not allow sufficient time for APOBEC3B to induce mutations during tumour development, leading to only a few detectable SNVs with low allelic frequency. Carcinogen-induced tumours tend to be less aggressive than GEMMs and develop more slowly. To extend the length of tumour development, we exposed the mice to urethane before $A 3 B i$ expression. Urethane is a carcinogen which induces $A>T / G$ substitutions and initiates lung tumours by inducing an activating mutation at codon Q61 in Kras ${ }^{21,22}$. We generated two models, where we initiated tumours with urethane and induced $\mathrm{A} 3 \mathrm{Bi}$ in Rosa26 ${ }^{\mathrm{ABB}}$ mice using AdCre (UrA3Bi-AdCre), to cause induction of $\mathrm{A} 3 \mathrm{Bi}$ locally in the lung, or through the activation of ubiquitously expressed CreER with tamoxifen in Rosa26 $6^{A B i / C r e E R(t 2)}$ mice (UrA3Bi-CreER), causing expression of $\mathrm{A} 3 \mathrm{Bi}$ in all tissues. Since APOBEC mutations are often late events in tumour evolution ${ }^{19}$, we delayed the induction of A3B by three weeks after the first injection of urethane (Supplementary Fig. 4A).

We confirmed the expression of $\mathrm{A} 3 \mathrm{Bi}$ in the lungs after delivery of tamoxifen in the Rosa26 $6^{A 3 B i / C r e E R(t 2)}$ mice or AdCre in the Rosa26 ${ }^{A 3 B i}$ mice (Fig. 3A). Unexpectedly, $\mathrm{A} 3 \mathrm{Bi}$ expression was lower in the tumours compared with adjacent lungs (Fig. 3A, B, C). Despite that, UrA3Bi-CreER tumours had more advanced histological grades and showed increased levels of intratumoural necrosis compared with tumours induced by urethane alone (Fig. 3D, E). However, tumour growth and the number of tumours per animal were similar between urethane and UrA3Bi-CreER tumours (Supplementary Fig. 4B, C). We performed WES to assess whether A3Bi generated mutations in these tumours. As expected, WES revealed that urethane exposure led to a large number of clonal exonic SNVs (Fig. 3F and Supplementary Fig. 5A). A3Bi expression increased tumour mutational burden particularly in the UrA3Bi-CreER tumours and increased the number and proportion of subclonal SNVs (Fig. 3F and Supplementary Fig. 5B and $C)$. APOBEC specific mutations $(T(C>T / G))$ were mainly sub-clonal, particularly in the UrA3Bi-CreER tumours, as illustrated by the increase in low allelic frequency APOBEC mutations in Supplementary Fig. 5D. These results suggest that $\mathrm{A} 3 \mathrm{Bi}$ was expressed and active in these tumours. 
bioRxiv preprint doi: https://doi.org/10.1101/2020.12.22.423126; this version posted December 22, 2020. The copyright holder for this preprint (which was not certified by peer review) is the author/funder, who has granted bioRxiv a license to display the preprint in perpetuity. It is made available under aCC-BY 4.0 International license.

de Carné, Boumelha, Law et al.

22 December 2020

To investigate whether the presence of A3Bi-induced mutations could alter the tumour immune infiltrate, we carried out flow cytometry and qPCR on urethane and UrA3Bi-CreER tumours. We chose to focus on the A3Bi-CreER tumours because in the UrA3Bi-AdCre model, only cells infected by the adenovirus express A3Bi, limiting the chance that $\mathrm{A} 3 \mathrm{Bi}$ is expressed in all tumour cells, whereas all epithelial cells expressed $\mathrm{A} 3 \mathrm{Bi}$ in the UrA3Bi-CreER model (supplementary figure 2J). Flow cytometry and qPCR showed a decrease in $\mathrm{CD}^{+} \mathrm{T}$ cells in UrA3Bi tumours compared with normal lungs (Supplementary Fig. 6A, B). In contrast, we observed an increase in early $\left(\mathrm{CD} 69^{+}\right)$and late $\left(\mathrm{PD}-1^{+}\right)$activated $\mathrm{CD} 8^{+}$and $\mathrm{CD} 4^{+} \mathrm{T}$ cells in comparison with normal lungs, an increase in memory effector CD8 ${ }^{+}$and $C D 4^{+} \mathrm{T}$ cells and an increase in exhausted (LAG-3 ${ }^{+}$) CD8 ${ }^{+} \mathrm{T}$ cells (Fig. 3G, H). Although less present, the CD8 ${ }^{+} \mathrm{T}$ cells present in UrA3Bi tumours were more activated and exhausted.

Since we observed activated $T$ cells in the tumour microenvironment of UrA3BiCreER tumours, we treated tumour-bearing mice with a combination of anti-PD-1 and anti-CTLA-4 to assess whether ICB could elicit an immune response. This combination therapy failed to control tumour growth (Fig. 3I). To summarise, these data suggest that APOBEC3B induced subclonal mutations in carcinogen-induced models of lung cancer and promoted less differentiated tumours. However, despite the presence of activated $T$ cells in the tumour bed, these tumours did not respond to conventional ICB.

\section{Establishment of immunogenic clonal cell lines from KPA and KPAR tumours}

We hypothesised that the lack of immunogenicity in APOBEC3B-expressing autochthonous tumours was due to the subclonality of mutations, which have been shown to be less effective at generating effective adaptive immune responses ${ }^{23,24}$. We therefore established cell lines from these models which were subsequently singlecell cloned to increase the frequency of clonal neoantigens. The immunogenicity of different single-cell clones was assessed by comparing the growth of cells subcutaneously transplanted into syngeneic immune-competent (WT) and immunedeficient $\left(\operatorname{Rag}^{1^{-/}}\right)$mice. Cells taken from urethane-induced tumours grew poorly in vitro and failed to grow when transplanted into mice. However, a number of cell lines were readily established from KPA and KPAR autochthonous tumours and single-cell cloned. KPAR1.1 cells grew similarly when injected into WT and Rag $1^{-1-}$ mice whilst another clone KPAR1.3 grew more slowly in WT mice compared to Rag 1/- $^{\text {mice }}$ (Fig. 
bioRxiv preprint doi: https://doi.org/10.1101/2020.12.22.423126; this version posted December 22, 2020. The copyright holder for this preprint (which was not certified by peer review) is the author/funder, who has granted bioRxiv a license to display the preprint in perpetuity. It is made available under aCC-BY 4.0 International license.

de Carné, Boumelha, Law et al.

22 December 2020

4A). Several additional immunogenic and non-immunogenic clonal cell lines were also established from KPA and KPAR autochthonous tumours, showing varying levels of differential growth when transplanted into immune-competent and Rag $1^{-1-}$ mice (Supplementary Fig. 7).

We carried out WES to assess the mutational burden of the KPAR1.1 and KPAR1.3 clonal cell lines, the parental polyclonal cell line (KPAR P) and another autochthonous KPAR tumour taken from the same mouse. Single-cell cloning increased the frequency of clonal mutations, some of which were not detected in the parental cell line (Fig. 4B). KPAR1.3 cells contained more clonal mutations compared to KPAR1.1 cells, and also KP tumours (Fig. $2 \mathrm{H}$ ), which resulted in an increased number of clonal neoantigens (Fig. 4C). Note that the autochthonous KPAR tumour contained no clonal neoantigens. We were unable to detect $A P O B E C 3 B$ mRNA expression in any of the cell lines (Fig. 4D), suggesting that expression of the transgene was downregulated during tumour growth or the establishment of the cell lines. Importantly, orthotopic KPAR1.3 lung tumours, formed after tail vein injection of KPAR1.3 cells, did not express APOBEC3B (Fig. 4E), as the expression of a human recombinant protein could affect the growth of tumours in immune-competent hosts.

Together these results suggest that establishing single-cell clones from KPA and KPAR autochthonous tumours increased the frequency of clonal neoantigens resulting in the generation of cell lines that engaged with the adaptive immune system.

\section{KPAR1.3 tumours are responsive to ICB}

Given that the growth of KPAR1.3 tumours were partially restrained by adaptive immunity we tested the sensitivity of the model to ICB. Mice bearing subcutaneous KPAR1.3 tumours were treated with anti-PD-1, anti-CTLA-4 or a combination of both. Anti-CTLA-4 alone, or in combination with anti-PD-1, led to tumour regression in all mice, whilst anti-PD-1 alone failed to affect tumour growth. (Fig. 5A, and Supplementary Fig. 8A). Furthermore, anti-CTLA-4 or the combination of anti-CTLA4 and anti-PD-1 resulted in long-term durable regression for up to one year in $33 \%$ and $50 \%$ of mice, respectively (Fig. 5B). All treated mice that had rejected the primary tumour subsequently rejected a secondary tumour when re-challenged with KPAR1.3 cells on the opposite flank (Fig. 5B), demonstrating the establishment of immunological memory. 
bioRxiv preprint doi: https://doi.org/10.1101/2020.12.22.423126; this version posted December 22, 2020. The copyright holder for this preprint (which was not certified by peer review) is the author/funder, who has granted bioRxiv a license to display the preprint in perpetuity. It is made available under aCC-BY 4.0 International license.

de Carné, Boumelha, Law et al.

22 December 2020

Flow cytometry analysis of subcutaneous tumours treated with anti-CTLA-4 or antiPD-1 demonstrated that only anti-CTLA-4 treatment effectively depleted Foxp3 ${ }^{+}$ regulatory $\mathrm{T}$ cells (Tregs) (Fig. $5 \mathrm{C}$ ), resulting in an increase in the ratio of $\mathrm{CD} 8^{+}$and $\mathrm{CD}^{+}$effector $\mathrm{T}$ cells to Tregs (Supplementary Fig. 8B, C), as previously reported ${ }^{25}$.

Anti-CTLA-4 treatment also led to an increase in the frequency of effector memory and PD- $1^{+}$CD8 ${ }^{+}$T cells in tumours (Fig. 5D). To assess whether the sensitivity to ICB was dependent on the anatomic site of tumour growth, as previously shown ${ }^{26}$, we also treated orthotopic KPAR1.3 lung tumours with anti-PD-1, anti-CTLA-4 or a combination of both. KPAR1.3 cells were injected intravenously into mice which were subsequently treated once lung tumours were detected by micro-CT. In contrast to subcutaneous tumours, orthotopic tumours responded to both anti-CTLA-4 and antiPD-1 monotherapies, resulting in a significant increase in the survival of tumourbearing mice (Fig. 5E). Anti-PD-1 alone, or in combination with anti-CTLA-4 led to long-term responses in $20 \%$ of mice. Immunohistochemistry staining demonstrated that both anti-PD-1 and anti-CTLA-4 therapy increased the infiltration of CD8 ${ }^{+} \mathrm{T}$ cells into the tumour (Fig. 5F, and Supplementary Fig. 8D). This increase was greater in anti-PD-1 treated mice which correlates with the superior efficacy of anti-PD-1 monotherapy in the orthotopic setting. In contrast to subcutaneous tumours, antiCTLA-4 treatment failed to deplete Foxp3 ${ }^{+}$Tregs in orthotopic tumours (Fig. 5G, and Supplementary Fig. 8E). To summarise, KPAR1.3 tumours were sensitive to anti-PD1 or anti-CTLA-4 therapy, the response to which was dependent on the site of tumour growth.

\section{KPAR1.3 tumours generate an adaptive immune response}

We next used flow cytometry to characterise the tumour microenvironment of orthotopic lung tumours established from immunogenic KPAR1.3 cells and nonimmunogenic KPB6 cells, derived from the KP GEMM. Note that both KPAR1.3 and KPB6 cells were derived from, and transplanted into, pure C57BL/6J mice. The immune compartment of both tumour models differed significantly compared to normal lung with a large increase in the proportion of myeloid cells, consisting primarily of interstitial macrophages, and exclusion of $B$ cells and NK cells (Fig. 6A). KPB6 tumours contained significantly more myeloid cells than KPAR1.3 tumours, primarily due to an increased proportion of neutrophils (Supplementary Fig. 9A). Conversely, KPAR1.3 tumours showed significantly higher levels of $T$ cell infiltration, which was a 
bioRxiv preprint doi: https://doi.org/10.1101/2020.12.22.423126; this version posted December 22, 2020. The copyright holder for this preprint (which was not certified by peer review) is the author/funder, who has granted bioRxiv a license to display the preprint in perpetuity. It is made available under aCC-BY 4.0 International license.

de Carné, Boumelha, Law et al.

22 December 2020

result of increased $\mathrm{CD}^{+}$and $\mathrm{CD}^{+} \mathrm{T}$ cells and Tregs, as well as increased NK cell infiltration (Fig. 6B). Immunohistochemistry staining confirmed that KPAR1.3 tumours were more infiltrated with $\mathrm{CD}^{+} \mathrm{T}$ cells (Supplementary Fig. 9B). T cells infiltrating KPAR1.3 tumours were also more activated, with a higher proportion of effector memory CD8 ${ }^{+}$and $\mathrm{CD}^{+} \mathrm{T}$ cells (Fig. 6C) and increased expression of the activation marker CD44 on both $\mathrm{CD}^{+}$and $\mathrm{CD}^{+} \mathrm{T}$ cells (Supplementary Fig. 9C, D) as well as the early activation marker CD69 on $\mathrm{CD}^{+} \mathrm{T}$ cells (Supplementary Fig. 9E). Both CD8 ${ }^{+}$ and $\mathrm{CD}^{+} \mathrm{T}$ cells also showed increased expression of the immune checkpoint molecules PD-1, LAG-3 and TIM-3 in KPAR1.3 tumours (Fig. 6D). Furthermore, KPAR1.3 tumours also contained a significant proportion of PD-1/LAG-3 doublepositive $\mathrm{CD}^{+} \mathrm{T}$ cells which were completely absent in KPB6 tumours (Fig. 6E). There was also an increased proportion of PD-L $1^{+}$myeloid cells in KPAR1.3 tumours, indicative of a T-cell inflamed tumour microenvironment (Fig. 6F). In addition, immunohistochemical staining of KPAR1.3 tumour-bearing lungs revealed the presence of perivascular tertiary lymphoid structures (TLSs) consisting of large $\mathrm{Ki} 67^{+}$ $\mathrm{B}$ cell clusters which co-localised with $\mathrm{CD}^{+} \mathrm{T}$ cells (Fig. 6G). Consistent with a previous report ${ }^{13}$, TLSs were highly infiltrated with Foxp $3^{+}$Tregs (Supplementary Fig. 9F) which accumulated in these structures at significantly higher levels compared to tumours (Supplementary Fig. 9G). Taken together, these data demonstrate that orthotopic KPAR1.3 tumours generated an adaptive anti-tumour immune response which was absent in orthotopic KPB6 tumours.

\section{Generation of KPAR1.3G12C cells to assess the immunomodulatory properties of KRAS-G12C inhibitors}

The recently developed class of KRAS-G12C inhibitors has been shown to promote anti-tumour immune responses in syngeneic models of cancer ${ }^{8}$. In order to test the effect of KRAS-G12C inhibitors in the KPAR1.3 syngeneic model we used primeediting technology to edit the two KRAS ${ }^{\mathrm{G} 12 \mathrm{D}}$ alleles, generating heterozygous KPAR1.3 $3^{\mathrm{G} 12 \mathrm{D} / \mathrm{G} 12 \mathrm{C}}$ and homozygous KPAR1.3 $3^{\mathrm{G} 12 \mathrm{C} / \mathrm{G} 12 \mathrm{C}}$ cell lines (Supplementary Fig. 10A). Cell-viability assays demonstrated that both cells lines were sensitive to trametinib in vitro as was the parental cell line, but only the KPAR1.3 ${ }^{\mathrm{G} 12 \mathrm{C} / \mathrm{G} 12 \mathrm{C}}$ showed impaired viability on treatment with AZ-8037, a KRAS-G12C inhibitor (compound 25 in Kettle et al. ${ }^{27}$ (Supplementary Fig. 10B). Immunoblotting revealed that AZ-8037 inhibited pERK at $6 \mathrm{~h}$ and $24 \mathrm{~h}$ in the KPAR $1.3^{\mathrm{G} 12 \mathrm{C} / \mathrm{G} 12 \mathrm{C}}$ cell line to a similar level 
achieved with trametinib (Supplementary Fig. 10B). We then tested the response of subcutaneous KPAR1.3 ${ }^{\mathrm{G} 12 \mathrm{C} / \mathrm{G} 12 \mathrm{C}}$ (KPAR1.3 ${ }^{\mathrm{G} 12 \mathrm{C}}$ ) tumours to AZ-8037 in both immunecompetent (WT) and immune-deficient (Rag $\left.{ }^{-1-}\right)$ mice. Vehicle-treated KPAR1.3 ${ }^{\mathrm{G} 12 \mathrm{C}}$ tumours grew slower in WT mice compared to Rag $1^{-1 /}$ mice, similarly to what we observed with the parental KPAR1.3 tumours (Fig. 7A). AZ-8037 treatment caused marked tumour regression in both WT and Rag 1-- mice, however the response was more durable in WT mice as all tumours remained responsive during the duration of treatment whilst tumours in Rag1-- mice began to grow back before termination of treatment (Fig. 7A). Furthermore, after the treatment was terminated one of the five treated mice showed a durable cure (Fig. 7B). We also edited the KRAS ${ }^{\mathrm{G} 12 \mathrm{D}}$ allele of the KPB6 cell line using CRISPR technology to generate a $\mathrm{KPB}^{\mathrm{G} 12 \mathrm{Cl} /}\left(\mathrm{KPB6}^{\mathrm{G} 12 \mathrm{C}}\right)$ cell line (Supplementary Fig. 10D). Cell-viability assays and immunoblotting demonstrated that $\mathrm{KPB} 6^{\mathrm{G} 12 \mathrm{C}}$ cells were sensitive to both trametinib and AZ-8037 (Supplementary Fig. 10E, F). In contrast to KPAR1.3 $3^{\mathrm{G} 12 \mathrm{C}}$ tumours, the response of $\mathrm{KPB} 6^{\mathrm{G} 12 \mathrm{C}}$ tumours to AZ-8037 was comparable in immune-competent and Rag $1^{-1-}$ mice (Fig. 7C) and tumours grew back rapidly after the cessation of treatment with no long-term responses achieved (Fig. 7D). qPCR analysis of gene expression in orthotopic KPAR $1.3^{\mathrm{G} 12 \mathrm{C}}$ tumours revealed that KRAS-G12C inhibition reprogrammed the tumour microenvironment to favour anti-tumour immune responses with increased antigen presentation, cytokine production, interferon signalling, immune cell infiltration and $T$ cell activation (Fig 7E).

These results suggest the efficacy of KRAS-G12C inhibition in the immunogenic KPAR1.3 model was partially due to the generation of an adaptive anti-tumour immune response which resulted in durable regressions in immune-competent hosts. 
bioRxiv preprint doi: https://doi.org/10.1101/2020.12.22.423126; this version posted December 22, 2020. The copyright holder for this preprint (which was not certified by peer review) is the author/funder, who has granted bioRxiv a license to display the preprint in perpetuity. It is made available under aCC-BY 4.0 International license.

de Carné, Boumelha, Law et al.

22 December 2020

\section{DISCUSSION}

The role of the immune system in the control of tumour progression has been widely studied over the past decade. It is now evident that tumours acquire mechanisms to evade immune destruction, often by remodelling the tumour microenvironment, to promote growth and metastasis ${ }^{28,29}$. Investigating the interplay between the tumour and the immune system requires the use of animal models whereby tumour cells grow in the presence of an intact immune system. Unfortunately, current GEMMs of lung cancer lack the mutations that lead to neoantigen presentation, making them, as we have shown, poorly immunogenic and refractory to immunotherapy ${ }^{9,10,21}$. The broadly used KP model of lung adenocarcinoma does not mimic its human counterparts in terms of mutational load and immune infiltrate ${ }^{11,30}$. Carcinogen-induced models are also autochthonous and in contrast have a high TMB, but they are typically very slow to develop, making them challenging for preclinical studies. Moreover, as indicated in this study, there is little evidence that carcinogen-induced lung tumours are immunogenic. Instead, most preclinical studies of immunotherapy have utilised subcutaneous transplantation models; however, the tumours develop in a different environment than the tissue of origin. There is a need for improved models of lung cancer that are immunogenic to enable us to better understand the interplay between the tumour and the immune system and assess the efficacy of novel therapeutic interventions.

To address this issue, we chose to induce mutations by expressing the human DNA deaminase APOBEC3B, because enzymes of this family have been shown to be responsible for causing mutations in NSCLC ${ }^{14,19}$. We established the KPAR1.3 cell line from a single-cell clone of a KP tumour expressing APOBEC3B which had developed in an immune-deficient background and therefore could not undergo immune-editing. We used the KPAR1.3 cell line as an orthotopic transplantable model of lung cancer and demonstrated that this model was immunogenic. In contrast, the KPB6 cell line, established from a regular KP tumour, failed to recruit, activate or exhaust T cells. Moreover, KPAR1.3 tumours were associated with peri-vascular tertiary lymphoid structures (TLSs), which are often found in NSCLC patients ${ }^{31}$ and have recently been associated with response to immunotherapy and good prognosis in melanoma, sarcoma and renal cell carcinoma ${ }^{32-34}$. TLSs rarely form in mouse models of lung cancer except in autochthonous KP tumours expressing a model 
bioRxiv preprint doi: https://doi.org/10.1101/2020.12.22.423126; this version posted December 22, 2020. The copyright holder for this preprint (which was not certified by peer review) is the author/funder, who has granted bioRxiv a license to display the preprint in perpetuity. It is made available under aCC-BY 4.0 International license.

de Carné, Boumelha, Law et al.

22 December 2020

antigen consisting of ovalbumin peptides fused to luciferase (LucOS), where these structures were enriched in immunosuppressive Tregs $^{13}$. KPAR1.3 tumours recapitulated the formation of TLSs in the lung and the enrichment of Tregs in these structures, offering a good model for studying the role of TLSs in NSCLC, especially in the context of immunotherapy as, unlike KP-LucOS tumours ${ }^{9}$, KPAR1.3 tumours respond to ICB. Collectively, our data suggest that APOBEC3B mutations can produce neoantigens and elicit a $\mathrm{T}$ cell response in a Kras-driven, p53-deleted model of lung adenocarcinoma, which reproduces immune features often observed in patients.

Other murine lung cancer cell lines have been used in preclinical studies. The $3 \mathrm{LL}$ cell line originates from a spontaneous Lewis lung carcinoma tumour (also referred to as LL/2 or LLC1) and has been serially passaged in immune competent mice, leading to a highly immune evasive phenotype. 3LL tumours are characterised by a sparse $T$ cell infiltrate despite having a high TMB and are classified as immune-cold ${ }^{35}$. These tumours are therefore highly refractory to ICB and do not make a suitable model for studying the response to therapy in an immune-hot context. Cell lines derived from KP tumours - such as the KPB6 cell line used in this study - lack the mutations to generate neoantigens and induce a $\mathrm{T}$ cell response. One strategy to achieve neoantigen presentation has been the expression of model antigens such as the ovalbumin peptide. However, this approach resulted in rejection of the transplanted cells, or selection of clones that lost antigen expression, perhaps due to non-physiological levels of expression, or the high antigenicity, of the antigen ${ }^{10}$. These systems are therefore not suitable for studying the response to ICB.

We and others have tried several approaches to make lung cancer GEMMs more immunogenic. We treated KP mice with carcinogens, expressed APOBEC3B in p53deleted urethane-induced tumours, and - based on the assumption that chromosome rearrangement could lead to neoantigens - also expressed Mad2, a spindle checkpoint protein associated with aneuploidy, in KP tumours ${ }^{36}$. However, none of these strategies generated immunogenic tumours that grew differentially in immunecompetent and immune-deficient backgrounds, induced $\mathrm{T}$ cell responses or responded to ICB (unpublished data). APOBEC3B expression induced $T(C>T / G)$ specific mutations in KP and urethane-induced lung tumours, although it did not increase the TMB substantially and failed to make the tumours immunogenic. APOBEC mutations were mainly subclonal in the autochthonous tumours, as described in patients ${ }^{20}$. The subclonality of many mutations in these models could 
bioRxiv preprint doi: https://doi.org/10.1101/2020.12.22.423126; this version posted December 22, 2020. The copyright holder for this preprint (which was not certified by peer review) is the author/funder, who has granted bioRxiv a license to display the preprint in perpetuity. It is made available under aCC-BY 4.0 International license.

de Carné, Boumelha, Law et al.

22 December 2020

explain the absence of effective anti-tumour immune responses we observe, since sensitivity to ICB correlates with clonal neoantigen burden in NSCLC 37 . However, we were able to generate immunogenic cell lines through single-cell cloning of nonimmunogenic $\operatorname{KPA}(\mathrm{R})$ tumours, presumably by increasing the frequency of clonal mutations. Interestingly, UrA3Bi tumours had a higher number of clonal mutations than KPAR1.3 tumours but were still refractory to ICB. This suggests that urethane-induced mutations may be poorly immunogenic and also highlights the potential differences in the ability of transplantable and autochthonous models to induce adaptive immune responses, as previously reported ${ }^{10}$.

Despite the link between APOBEC mutational signature and intra-tumour heterogeneity, the proportion of APOBEC-induced mutations has been associated with a favourable response to ICB in bladder, head and neck squamous cell carcinoma and NSCLC ${ }^{38,39}$. However, the proportion of APOBEC mutations also correlated with $T M B$, which is a predictor of response to ICB in these cancers ${ }^{40-42}$. Although we observed APOBEC-induced mutations in the UrA3Bi model, these tumours remained refractory to ICB. The direct link between APOBEC mutations and immunogenicity remains to be demonstrated.

The majority of studies utilising transplantable cell lines involve subcutaneous transplantation into syngeneic immune-competent mice. We observed a striking difference in the response to anti-PD-1 or anti-CTLA-4 in subcutaneous versus orthotopic tumours, as previously demonstrated for PD-1/PD-L1 blockade ${ }^{26}$. Subcutaneous KPAR1.3 tumours responded to anti-CTLA4 but were refractory to antiPD-1, although the mechanism of this intrinsic resistance is still unclear. Anti-CTLA-4 can induce tumour regression through the depletion of Tregs in subcutaneous tumours ${ }^{25}$. We validated this observation in subcutaneous KPAR1.3 tumours but observed that anti-CTLA-4 was not sufficient to deplete Tregs in the orthotopic setting, presumably due to the absence of the relevant Fcy-receptor expressing macrophages in the lung tumour microenvironment. This highlights the importance of studying tumours in their tissue of origin when assessing responses to ICB.

The recently developed KRAS-G12C specific inhibitors have produced outstanding responses in NSCLC ${ }^{43}$. A recent study showed that these inhibitors could promote $\mathrm{T}$ cell responses through increased IFNy signalling in the immunogenic CT26 ${ }^{\mathrm{G} 12 \mathrm{C}}$ transplantable model ${ }^{8}$. Similar to what was shown in this study, we observed profound 
changes in the tumour microenvironment in response to KRAS-G12C inhibition, indicative of enhanced anti-tumour immune responses. The tumour regression we observed after KRAS-G12C inhibition in KPAR1.3 ${ }^{\mathrm{G} 12 \mathrm{C}}$ tumours was more profound in immune-competent mice; however, this was not the case for non-immunogenic KPB6 ${ }^{\mathrm{G} 12 \mathrm{C}}$ tumours. This result confirms that the efficacy of KRAS-G12C inhibitors is partially due to the engagement of the adaptive immune system in immune-hot tumours. The KPAR1.3 model therefore offers the possibility to explore combinations of immunotherapy with KRAS-G12C inhibition to overcome the acquired resistance anticipated following this novel targeted therapy ${ }^{44}$.

In conclusion, we have created a novel model of immunogenic Kras-driven lung adenocarcinoma, which we anticipate will contribute to the development of new combinations of therapy. 
bioRxiv preprint doi: https://doi.org/10.1101/2020.12.22.423126; this version posted December 22, 2020. The copyright holder for this preprint (which was not certified by peer review) is the author/funder, who has granted bioRxiv a license to display the preprint in perpetuity. It is made available under aCC-BY 4.0 International license.

de Carné, Boumelha, Law et al.

22 December 2020

\section{METHODS}

\section{In vivo tumour studies}

$K$ ras $^{\mathrm{LSL}-\mathrm{G} 12 \mathrm{D} /+} ; \operatorname{Trp} 53^{\mathrm{fl} / \mathrm{fl}}$ mice $(\mathrm{KP})$ were sourced from the Mouse Models of Human Cancer Consortium. Kras ${ }^{\mathrm{LSL}-\mathrm{G} 12 \mathrm{D} /+} ; \operatorname{Trp}^{\mathrm{ffl/fl} ;}$ Rosa26 $6^{\mathrm{ABB}}$ mice (KPA) and Kras ${ }^{\mathrm{LSL}-}$ G12D/+;Trp53 ${ }^{\mathrm{fl} / \mathrm{fl}} ;$ Rosa26 ${ }^{\mathrm{A} 3 \mathrm{Bi} ;} ; \operatorname{Rag}^{\mathrm{KO} / \mathrm{KO}}$ mice (KPAR) were generated by breeding KP mice with Rosa26 ${ }^{\mathrm{A} 3 \mathrm{Bi}}$ mice and Rag $1^{\mathrm{KO} / \mathrm{KO}}$ mice (see supplement for development and validation of the Rosa26::LSL-A3Bi model). Tumours were induced by intratracheal intubation of $1 \times 10^{6}$ adenovirus expressing Cre recombinase as previously described ${ }^{45}$. Tumour volume was assessed via micro-CT scanning.

For the urethane-induced models, tumours were induced by 3 intra-peritoneal injections of $1 \mathrm{mg} / \mathrm{g}$ of urethane over the period of a week. Three weeks following urethane first injection, APOBEC3Bi was induced by 3 doses of $100 \mathrm{mg} / \mathrm{g}$ tamoxifen over a period of a week in Rosa26 $6^{A B B / C r e E R(t 2)}$ mice (UrA3Bi-CreER), or by intratracheal intubation of $1 \times 10^{6}$ adenovirus expressing Cre recombinase in Rosa26 ${ }^{A 3 B i}$ mice (UrA3Bi-AdCre). Tumour volume was assessed via micro-CT scanning.

All transplantation animal experiments were carried out using 8-12-week C57BL/6 mice. For subcutaneous studies, $1.5 \times 10^{5} \mathrm{KPAR} 1.3$ or KPAR1.3 $3^{\mathrm{G} 12 \mathrm{C}}$ cells and $5 \times 10^{5}$ KPB6 ${ }^{\mathrm{G} 12 \mathrm{C}}$ cells (1:1 mix with matrigel) were injected subcutaneously into the flank. Tumour volume was measured twice weekly and calculated using the formula $0.5 \mathrm{x}$ [Length $x$ Width $\left.^{2}\right]$. Mice were euthanised when the average tumour dimensions exceeded $1.5 \mathrm{~mm}$. For re-challenge experiments, mice that remained tumour-free for 4 months were injected subcutaneously into the opposite flank with $1.5 \times 10^{5} \mathrm{KPAR} 1.3$ tumour cells. For orthotopic studies, $1.5 \times 10^{5} \mathrm{KPAR} 1.3$ cells, $1 \times 10^{5} \mathrm{KPAR} 1.3^{\mathrm{G} 12 \mathrm{C}}$ and KPB6 cells were injected intravenously into the tail-vein. Mice were euthanised when the humane endpoint of $15 \%$ weight loss was reached.

For treatments, $200 \mu \mathrm{g}$ anti-PD-1 (clone RMP1-14, BioXcell) and $200 \mu \mathrm{g}$ anti-CTLA4 (clone 9H10, BioXcell), or their respective IgG controls, were administered per mouse via intraperitoneal injection twice weekly for a maximum of three weeks. AntiPD-L1 (clone 10F.9G2, BioXcell) or the respective IgG control were administered at $10 \mathrm{mg} / \mathrm{kg}$ via intraperitoneal injection twice weekly, for two weeks. AZ-8037 or vehicle (10\% Pluronic-F127) was administered 5 days per week via oral gavage at $100 \mathrm{mg} / \mathrm{kg}$. Mice were randomised into groups and treatments initiated once tumours reached an 
bioRxiv preprint doi: https://doi org/10.1101/2020.12.22.423126; this version posted December $22,2020$. The copyright holder for this preprint (which was not certified by peer review) is the author/funder, who has granted bioRxiv a license to display the preprint in perpetuity. It is made available under aCC-BY 4.0 International license.

de Carné, Boumelha, Law et al.

22 December 2020

average volume of $150 \mathrm{~mm}^{3}$ for subcutaneous studies or were detectable by microCT for orthotopic experiments.

\section{Cell lines}

The KPB6 cell line was obtained from Cell Services at the Francis Crick Institute. KPAR and KPA cell lines were established by cutting up lung tumours into small pieces and culturing in DMEM-F12 supplemented with Glutamax®, FBS (10\%), hydrocortisone (1 uM), EGF (20 ng/ml), IGF (50 ng/ml), penicillin (100 units $/ \mathrm{mL})$ and streptomycin $(100 \mu \mathrm{g} / \mathrm{mL})$. KPAR, KPA and KPB6 cell lines were cultured in DMEM supplemented with fetal bovine serum (10\%), L-glutamine (2 mM), penicillin (100 units $/ \mathrm{mL})$ and streptomycin $(100 \mu \mathrm{g} / \mathrm{mL})$. Clonal cells were derived by single-cell dilution into 96 well plates. Cell lines were routinely tested for Mycoplasma.

\section{Flow cytometry}

Mouse tumours were cut into small pieces, incubated with collagenase $(1 \mathrm{mg} / \mathrm{ml}$; ThermoFisher) and DNase I (50 U/ml; Life Technologies) for $45 \mathrm{~min}$ at $37^{\circ} \mathrm{C}$ and filtered through $70 \mu \mathrm{m}$ strainers (Falcon). Red blood cells were lysed for 5 min using ACK buffer (Life Technologies). Cells were stained with fixable viability dye eFluor870 (BD Horizon) for $30 \mathrm{~min}$ and blocked with CD16/32 antibody (Biolegend) for $10 \mathrm{~min}$. Cells were then stained with one of three antibody cocktails for 30 min (see Supplementary Table 1). Intracellular staining was performed using the Fixation/Permeabilization kit (eBioscience) according to the manufacturer's instructions. Samples were resuspended in FACS buffer and analysed using a BD Symphony flow cytometer. Data was analysed using FlowJo (Tree Star).

\begin{tabular}{|l|l|l|}
\hline Mix 1 & Mix 2 & Mix 3 \\
\hline CD3 [17A2], FITC & CD45 [30-F11], PerCP & MHC-II [M5/114.15.2], FITC \\
\hline CD45 [30-F11], PerCP & CD49b [DX5], AF488 & CD45 [30-F11], PerCP \\
\hline Foxp3 [FJK-16s], eFluor660 & NKp46 [29A1.4], BV421 & TIM3 [RMT3-23], PE \\
\hline CD44 [IM7], BV421 & F4/80 [EMR1], BV785 & CD103 [M290], BV421 \\
\hline CD69 [JES5-16E3], BV605 & Ly6G [1A8], BV711 & CD24 [M1/69], BV605 \\
\hline CD62L [MEL-14], BV711 & Ly6C [HK.14], BV785 & CD206 [C068C2], BV711 \\
\hline PD-1 [29F.1A12], BV785 & CD11c [HL3], BUV395 & CD86 [GL-1], BV785 \\
\hline CD8 [53-6.7], BUV395 & B220 [RA3-6B2], BV605 & CD11c [HL3], BUV395 \\
\hline CD4 [GK1.5], BUV737 & CD11b [M1/70], BUV395 & CD11b [M1/70], BUV737 \\
\hline
\end{tabular}




\begin{tabular}{|l|l|l|}
\hline TIM-3 [RMT3-23], PE & CD19 [6D5], PE & PD-L1 [MIH5], PE \\
\hline LAG-3 [eBioC9B7W], PE-Cy7 & PD-L1 [MIH5], PE-Cy7 & CD64 [X54-5/7.1], PE-Cy7 \\
\hline
\end{tabular}

\section{Histopathology and Immunohistochemistry}

Tumour-bearing lungs were fixed in $10 \%$ NBF for $24 \mathrm{~h}$ followed by $70 \%$ ethanol. Fixed tissue was embedded in paraffin wax. Tissue sections were stained with haematoxylin and eosin, using standard methods. Sections were examined by two board-certified veterinary pathologists (ASB and SLP). The tumour grade (adenoma, well-, or moderately well-differentiated carcinoma) was defined as follows, adenoma; mild pleomorphism, anisocytosis and anisokaryosis and well-circumscribed, welldifferentiated carcinoma; mild to moderate pleomorphism, anisocytosis and anisokaryosis and increased mitotic activity, and moderately well-differentiated carcinoma; as well-differentiated carcinoma but with evidence of invasion. Tumour necrosis was the proportion (as a percentage) of the total tumour nodule that was necrotic. When multiple tumour nodules were present within the lungs, the grade and percentage of necrosis related to the nodule with the highest grade and largest region of necrosis.

For immunohistochemistry staining, tissue sections were boiled in sodium citrate buffer (pH 6.0) for 15 min and incubated with the following antibodies for $1 \mathrm{~h}$ : anti-Ki67 (MIB-1, Agilent), anti-Foxp3 (D6O8R, CST), anti-CD8 (4SM15, Thermo Scientific), anti-B220 (RA3-6B2, BD Biosciences) and anti-A3Bi (5210-87-13) ${ }^{46}$. Primary antibodies were detected using biotinylated secondary antibodies and detected by HRP/DAB. Slides were imaged using a Leica Zeiss AxioScan.Z1 slide scanner.

\section{Micro-CT imaging}

Mice were anesthetised by inhalation of isoflurane and scanned using the Quantum

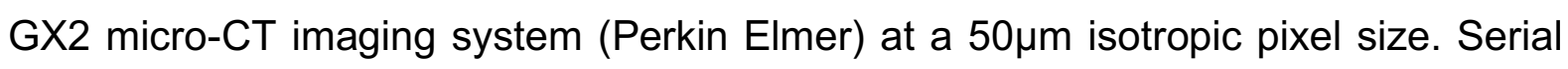
lung images were reconstructed and tumour volumes subsequently analysed using Analyse (AnalyzeDirect).

\section{Exome sequencing and neoantigen prediction}

Genomic DNA was extracted from tumours, cell lines and mouse tails using DNeasy Blood \& Tissue kit (Qiagen). Exome libraries were prepared by the Advanced Sequencing Facility at the Crick and sequenced using an Illumina HiSeq 4000 using 100 base pair paired-end reads. We aligned the reads to the GRCm38 mouse genome 
bioRxiv preprint doi: https://doi.org/10.1101/2020.12.22.423126; this version posted December 22, 2020. The copyright holder for this preprint (which was not certified by peer review) is the author/funder, who has granted bioRxiv a license to display the preprint in perpetuity. It is made available under aCC-BY 4.0 International license.

de Carné, Boumelha, Law et al.

22 December 2020

(Ensembl, release-86) using bwa mem (v0.7.15) ${ }^{47}$. We processed all alignment files using samtools $(\mathrm{v} 1.4)^{48}$. We identified and marked duplicates using Picard MarkDuplicates (v2.1.1, Java v1.8.0_92). We realigned indel regions using GATK RTCreator and indelRealign (v4.1.3.0, Java $v 1.8)^{49}$. We called germline mutations in each of the normal tail samples using Mutect2 (GATK v4.1.3.0). We used these tail germline calls to construct a 'panel of normals' (PON) which we used for downstream somatic mutation calling. We called tumour specific somatic mutations against matched tail samples from the same animal using Mutect1 (v1.1.7) and Mutect2 (GATK v4.1.3.0). We used C57BL mouse strain germline SNPs from the Mouse Genome Project ${ }^{49}$ to filter for known germline variants. (Mutect1 -dbsnp; Mutect2 SelectVariants -discordance, gatk CreateSomaticPanelOfNormal --germlineresource). We created a PON using gatk GenomicsDBImport and CreateSomaticPanelOfNormal (v4.1.3.0, Java v1.8). We generated Mutect2 calls using gatk Mutect2, FilterMutectCalls and SelectVariants sub-commands. We annotated SNVs using the predictCoding() function from the VariantAnnotation Bioconductor package (v1.26.1, R v3.5.1). We identified regions of relative copy number variation between the tumour and matched tail samples using cnvkit batch ${ }^{50}$ (v0.9.5, default parameters) (annotation as above).

We corrected variant allele frequencies for tumour purity using two different methods depending on the model. In the case of the KP induced tumours we calculated the ratio of reads per base across the floxed exons of Trp53 (1-9) and the undeleted exon 11. In the cases of the Urethane induced models we used the VAF of the Kras Q61 mutation. We assumed this mutation to be the primary driver of tumour activation since it is found in all the urethane induced tumours. All Kras Q61 loci were found to be copy number neutral. We called absolute copy number counts from the relative ratios using cnvkit call. The ratios were scaled using the purity estimates calculated above and integer ccopy numbers assigned using the follow log2 ration thresholds, with used these tumour purity estimates and the relative copy number ratios to call

We distinguished clonal from sub-clonal mutations by estimating the fraction of tumour cells carrying the observed mutation using the method detailed in Turajlic et al. ${ }^{51}$. Briefly we calculated the expected VAFs, given a tumour purity estimate, across a range of tumour cell fractions carrying the mutation [00.1, $00.2 \ldots 1$ ] and possible mutation copy numbers ranging from 1 to the reported absolute copy number reported 
above. We selected the tumour cell fraction and mutation copy number that gave an expected VAF closest to the observed. In situations where the expected VAFs for different mutation copy numbers were all close to the observed the more likely mutant copy number was selected. We classified an SNV as clonal if it was found in $>75 \%$ of the tumour cells, subclonal if less. We corrected purity normalized VAFs for CNV so reported VAFs were assumed to be diploid.

Mutated peptide sequences were processed using NetMHC4.0 with $k$-mer of 8-11 length. Rank threshold of 0.5 , or 2.0, were used to identify putative strong, or weak, MHC class I (H2-Kb and H2-Db) binders, respectively.

\section{qPCR}

Total RNA was extracted from cell lines or frozen tumour samples using RNeasy kit (Qiagen). Frozen tumour samples were homogenised prior to RNA extraction either using a syringe and needle or QIAshredder columns (Qiagen). cDNA was synthesised using Maxima First Strand cDNA Synthesis Kit (Thermo Fisher Scientific) and qPCR was performed using Applied Biosystems ${ }^{\text {TM }}$ Fast SYBR ${ }^{\text {TM }}$ Green Master Mix (Thermo Fisher Scientific). mRNA relative quantity was calculated as previously described ${ }^{52}$ and normalised to at least three housekeeping genes.

\begin{tabular}{lll}
\hline Target & Forward primer & Reverse primer \\
\hline A3Bi & GACCCTTTGGTCCTTCGAC & GCACAGCCCCAGGAGAAG \\
Adgre1 & ACCCTGGGACAAACACTTGG & GTGTCAGTGCAGGTGGCATA \\
Arg1 & ATGGGCAACCTGTGTCCTTT & TTCCCCAGGGTCTACGTCTC \\
Cd19 & TCTCACTGACCGGCCTGTAT & ATTTCAATGTGAGGCGGGTG \\
Cd274 & AGAGGCACGTGAAGGTCATT & ACTGGGACTATCCATCCACCA \\
Cd3e & CCTCCTAGCTGTTGGCACTT & AGGATGTGTTGCAGGCAGTT \\
Cd86 & GCTTCAGTTACTGTGGCCCT & TGTCAGCGTTACTATCCCGC \\
Cd8b1 & GACGAAGCTGACTGTGGTTGA & GCAGGCTGAGGGTGGTAAG \\
Ciita & CAAGGATCTTCCTGCCATCCG & CCAGGTGTTGCAGAGAAGAGA \\
Cxcl10 & ATGACGGGCCAGTGAGAATG & TCGTGGCAATGATCTCAACAC \\
Cxcl11 & GAAGGTCACAGCCATAGCCC & CTCTGCCATTTTGACGGCTT \\
Cxcl13 & ATTCAAGTTACGCCCCCTGG & TTGGCACGAGGATTCACACA \\
Cxcl9 & CCAAGCCCCAATTGCAACAAA & GTCCGGATCTAGGCAGGTTT \\
Dusp6 & GAGCCAAAACCTGTCCCAGT & GTGACAGAGCGGCTGATACC \\
Eomes & GCGCATGTTTCCTTTCTTGAG & GGTCGGCCAGAACCACTTC \\
Foxp3 & CAGAGAGAAGTGGTGCAGTCTC & GGCTACGATGCAGCAAGAGC \\
Gzmb & CTGTGCTGGCGCTTTGATTG & TGAGTGAGCCCCAAGAATGAA \\
H2d1 & Quantitect
\end{tabular}




\begin{tabular}{lll} 
H2k1 & TGAGAAGGAGAAACACAGGTGGAAA & TGGTGTAGAGGGGTGGACTG \\
Ifng & ACAGCAAGGCGAAAAGGATG & TGGTGGACCACTCGGATGA \\
Ifr9 & GCGTACCCTGGAAGCATTTC & GCACAGCGGAAGTTGGCT \\
Il10 & GCCGAGTGGTGGGTAAGAC & GCAAAGGCGCTGAACAAGAG \\
Irf1 & AGGCGCTGTCATCGATTTCT & ATGGCCTTGTAGACACCTTGG \\
Itgae & ATCCCTGGCTAGAGATGCAG & CTCCGGAACAGACAGGCATC \\
Lag3 & CAGCTCAATGCCACTGTCAC & GTCACATCCACATCCACCGT \\
Ly6c & GCAGTGCTACGAGTGCTATGG & ACTGACGGGTCTTTAGTTTCCTT \\
Ly6g & TGTATTGGGGTCCCACCTGA & TGGGAAGGCAGAGATTGCTC \\
Ncr1 & CTTGCACCTACCGACCCTAC & TTGTGTGATCCCAGAAGGCG \\
Nos2 & GGAATGGAGACTGTCCCAGC & CGATGTCATGAGCAAAGGCG \\
Pdcd1 & ACCCTGGTCATTCACTTGGG & CATTTGCTCCCTCTGACACTG \\
Prf1 & TGGAGGTTTTTTACCAGGC & TAGCCAATTTTGCAGCTGAG \\
Socs1 & Quantitect & \\
Stat1 & AAGTCTGGCAGCTGAGTTCC & TCTTCGGTGACAATGAGAGGC \\
Stat2 & CCCTGGTCGACCTATTGCTG & CAAGAACTTTGCTCCAGCCG \\
Tap1 & CACAGAGAGGTGTTTCGGGC & CCTCAGTCACCCGAGATGTG \\
Tapbp & TCGTCATCACCATGGCAACA & AGAGGGAGAACCTTCCAGGG \\
Tbx21 & AACACACACGTCTTTACTTTCCA & CGTATCAACAGATGCGTACATGG \\
Tigit & GTCACAGGAGTGACTGTACTGG & GCTTCCAGGGGATGAGAGACT \\
Actb & AGATCAAGATCATTGCTCCTCCT & ACGCAGCTCAGTAACAGTCC \\
Hsp90ab1 & AGATTCCACTAACCGACGCC & TGCTCTTTGCTCTCACCAGT \\
Sdha & TCGACAGGGGATGGTTTG & TCATACTCATCGACCCGCAC \\
Tbp & AGAACAACAGCCTTCCACCT & GGTGTTCTGAATAGGCTGTGGA \\
\hline & &
\end{tabular}

\section{Tumour Cell Viability}

For short-term viability assays, $1.5 \times 10^{3} \mathrm{KPAR} 1.3^{\mathrm{G} 12 \mathrm{C}}$ or $2 \times 10^{3} \mathrm{KPB}^{\mathrm{G} 12 \mathrm{C}}$ cells were seeded in 96-well plates and grown in the presence of different inhibitors for 72 h. Cell viability was assessed using CellTiter-Blue (Promega).

\section{Western blotting}

Cells were lysed using protein lysis buffer (Sigma) with protease and phosphatase inhibitor cocktails (Sigma). Protein concentration was determined using a BCA protein assay kit (Pierce). $15-20 \mu \mathrm{g}$ of protein was separated on a $4-12 \%$ Bis-Tris gel (Life Technologies) and transferred to PVDF membranes. Protein expression was detected by Western blotting using the following primary antibodies against: S6 (54D2, Cell Signalling), p-S6 (Ser235/236) (2211, Cell Signalling), Erk1/2 (3A7, Cell Signalling), p-Erk1/2 (Thr202/Tyr204) (9101, Cell Signalling), Akt (40D4, Cell Signalling), p-Akt (Ser473) (D9E, Cell Signalling), and Vinculin (VIN-11-5, Sigma). Primary antibodies 
bioRxiv preprint doi: https://doi.org/10.1101/2020.12.22.423126; this version posted December 22, 2020. The copyright holder for this preprint (which was not certified by peer review) is the author/funder, who has granted bioRxiv a license to display the preprint in perpetuity. It is made available under aCC-BY 4.0 International license.

de Carné, Boumelha, Law et al.

22 December 2020

were detected with HRP-conjugated anti-rabbit or anti-mouse IgG and visualised with Immobilon Western HRP substrate (Merck). 
bioRxiv preprint doi: https://doi.org/10.1101/2020.12.22.423126; this version posted December 22, 2020. The copyright holder for this preprint (which was not certified by peer review) is the author/funder, who has granted bioRxiv a license to display the preprint in perpetuity. It is made available under aCC-BY 4.0 International license.

de Carné, Boumelha, Law et al.

22 December 2020

\section{ACKNOWLEDGEMENTS}

We thank the science technology platforms at the Francis Crick Institute including Biological Resources, Scientific Computing, Bioinformatics and Biostatistics, Flow Cytometry, Experimental Histopathology, and Cell Services. We also thank Colleen Forster and Gerard O'Sullivan for assistance with immunohistochemistry and pathology, Yasuhiko Kawakami for sharing CMV-Cre animals, and Brian Dunnette for expertise with the Aperio ScanScope XT at the University of Minnesota.

Funding: This work was supported by funding to J.D. from the Francis Crick Institutewhich receives its core funding from Cancer Research UK (FC001070), the UK Medical Research Council (FC001070), and the Wellcome Trust (FC001070)-from the European Research Council Advanced Grant RASImmune, from a Wellcome Trust Senior Investigator Award 103799/Z/14/Z, and with support from a Cancer Research UK Cancer ImmunoTherapy Accelerator Award (CITA-CRUK; C33499/A20265). The $A 3 B i$ minigene model was developed with support from the National Cancer Institute P01-CA234228 (RSH), Team Judy (RSH), Randy Shaver Cancer Research and Community Fund (RSH), University of Minnesota Masonic Cancer Center, and College of Biological Sciences (RSH). RSH is the Margaret Harvey Schering Land Grant Chair for Cancer Research, a Distinguished University McKnight Professor, and an Investigator of the Howard Hughes Medical Institute. S.C.T received funding from the European Union's Horizon 2020 research and innovation programme under the Marie Sklodowska-Curie grant agreement No 703228

Competing interests: J.D. has acted as a consultant for AstraZeneca, Bayer, Jubilant, Theras, Vividion and Novartis. R.S.H is a co-founder, shareholder, and consultant of ApoGen Biotechnologies Inc. S.R. is an employee of AstraZeneca. C.S. receives grant support from Archer Dx, AstraZeneca, Boehringer-Ingelheim and Ono Pharmaceutical; has consulted for AstraZeneca, Bicycle Therapeutics, Celgene, Genentech, GRAIL, GSK, Illumina, Medicxi, MSD, Novartis and the Sarah Cannon Research Institute; receives grant support and has consulted for Bristol Myers Squibb, Pfizer and Roche-Ventana; is an advisory board member and is involved in trials sponsored by AstraZeneca; has stock options in Apogen Biotechnologies, Epic Sciences, GRAIL; and has stock options and is a co-founder of Achilles Therapeutics. The other authors declare that they have no competing interests.

Author contributions: S.C.T, J.B., E.K.L., R.S.H. and J.D. designed the study, interpreted the results and wrote the manuscript. S.C.T, J.B., P.R.C., M.M-A., M.A.C., 
S.R., E.M. and D.H. performed the biochemical experiments, C.M. assisted with in vivo studies, P.P.A., C.D., A.S.B., S.P. performed pathological studies, S.H. and P.E. performed bioinformatics analyses, R.S.H. designed the A3B knock-in model, supervised validation studies, contributed support and reagents, obtained funding, and edited the manuscript. E.K.L. created DNA constructs, performed validation studies, and conducted full body expression experiments. W.L.B., L.K.L., and C.D. provided technical and logistical assistance. R.I.V. provided statistical analysis. All authors contributed to manuscript revision and review. 
bioRxiv preprint doi: https://doi.org/10.1101/2020.12.22.423126; this version posted December 22, 2020. The copyright holder for this preprint (which was not certified by peer review) is the author/funder, who has granted bioRxiv a license to display the preprint in perpetuity. It is made available under aCC-BY 4.0 International license.

de Carné, Boumelha, Law et al.

22 December 2020

\section{REFERENCES}

1. Bray, F. et al. Global cancer statistics 2018: GLOBOCAN estimates of incidence and mortality worldwide for 36 cancers in 185 countries. CA. Cancer J. Clin. 68, 394-424 (2018).

2. Siegel, R. L., Miller, K. D. \& Jemal, A. Cancer statistics, 2020. CA. Cancer J. Clin. 70, 7-30 (2020).

3. Collisson, E. A. et al. Comprehensive molecular profiling of lung adenocarcinoma: The cancer genome atlas research network. Nature 511, 543-550 (2014).

4. Blumenschein, G. R. et al. A randomized phase II study of the MEK1/MEK2 inhibitor trametinib (GSK1120212) compared with docetaxel in KRAS-mutant advanced non-small-cell lung cancer (NSCLC). Ann. Oncol. 26, 894-901 (2015).

5. Borghaei, $\mathrm{H}$. et al. Nivolumab versus docetaxel in advanced nonsquamous non-small-cell lung cancer. N. Engl. J. Med. 373, 1627-1639 (2015).

6. Reck, M. et al. Pembrolizumab versus Chemotherapy for PD-L1-Positive NonSmall-Cell Lung Cancer. N. Engl. J. Med. 375, 1823-1833 (2016).

7. Coelho, M. A. et al. Oncogenic RAS Signaling Promotes Tumor Immunoresistance by Stabilizing PD-L1 mRNA. Immunity 47, 1083-1099 (2017).

8. Canon, J. et al. The clinical KRAS ( G12C ) inhibitor AMG 510 drives antitumour immunity. Nature 575, 217-223 (2019).

9. Pfirschke, C. et al. Immunogenic Chemotherapy Sensitizes Tumors to Checkpoint Blockade Therapy. Immunity 44, 343-354 (2016).

10. DuPage, M. et al. Endogenous T cell responses to antigens expressed in lung adenocarcinomas delay malignant tumor progression. Cancer Cell 19, 72-85 (2011).

11. McFadden, D. G. et al. Mutational landscape of EGFR- , MYC- , and Krasdriven genetically engineered mouse models of lung adenocarcinoma. Proc. Natl. Acad. Sci. 113, E6409-E6417 (2016).

12. Faget, J. et al. Neutrophils and Snail Orchestrate the Establishment of a Protumor Microenvironment in Lung Cancer. Cell Rep. 21, 3190-3204 (2017).

13. Joshi, N. S. et al. Regulatory T Cells in Tumor-Associated Tertiary Lymphoid Structures Suppress Anti-tumor T Cell Responses. Immunity 43, 579-590 (2015).

14. Burns, M. B., Temiz, N. A. \& Harris, R. S. Evidence for APOBEC3B mutagenesis in multiple human cancers. Nat. Genet. 45, 977-983 (2013).

15. Jackson, E. L. et al. The differential effects of mutant p53 alleles on advanced murine lung cancer. Cancer Res. 65, 10280-10288 (2005).

16. Ebert, P. J. R. et al. MAP Kinase Inhibition Promotes T Cell and Anti-tumor Activity in Combination with PD-L1 Checkpoint Blockade. Immunity 44, 609_ 
bioRxiv preprint doi: https://doi.org/10.1101/2020.12.22.423126; this version posted December 22, 2020. The copyright holder for this preprint (which was not certified by peer review) is the author/funder, who has granted bioRxiv a license to display the preprint in perpetuity. It is made available under aCC-BY 4.0 International license.

de Carné, Boumelha, Law et al.

22 December 2020

621 (2016).

17. Roberts, S. A. et al. An APOBEC cytidine deaminase mutagenesis pattern is widespread in human cancers. Nat. Genet. 45, 970-976 (2013).

18. Alexandrov, L. B. et al. The repertoire of mutational signatures in human cancer. Nature 578, 94-101 (2020).

19. De Bruin, E. C. et al. Spatial and temporal diversity in genomic instability processes defines lung cancer evolution. Science (80-. ). 346, 251-256 (2014).

20. Swanton, C., McGranahan, N., Starrett, G. J. \& Harris, R. S. APOBEC Enzymes: Mutagenic Fuel for Cancer Evolution and Heterogeneity. Cancer Discov. 5, 704-712 (2015).

21. Westcott, P. M. K. et al. The mutational landscapes of genetic and chemical models of Kras-driven lung cancer. Nature 517, 489-492 (2015).

22. Li, S., MacAlpine, D. M. \& Counter, C. M. Capturing the primordial Kras mutation initiating urethane carcinogenesis. Nat. Commun. 11, (2020).

23. Wolf, Y. et al. UVB-Induced Tumor Heterogeneity Diminishes Immune Response in Melanoma. Cell 179, 219-235 (2019).

24. McGranahan, N. et al. Clonal neoantigens elicit T cell immunoreactivity and sensitivity to immune checkpoint blockade. Science (80-. ). 351, 1463-1469 (2016).

25. Simpson, T. R. et al. Fc-dependent depletion of tumor-infiltrating regulatory $t$ cells co-defines the efficacy of anti-CTLA-4 therapy against melanoma. J. Exp. Med. 210, 1695-1710 (2013).

26. Li, H. Y. et al. The Tumor Microenvironment Regulates Sensitivity of Murine Lung Tumors to PD-1 / PD-L1 Antibody Blockade. Cancer Immun 5, 767-778 (2017).

27. Kettle, J. G. et al. Structure-Based Design and Pharmacokinetic Optimization of Covalent Allosteric Inhibitors of the Mutant GTPase KRASG12C. J. Med. Chem. 63, 4468-4483 (2020).

28. Hanahan, D. \& Weinberg, R. A. Hallmarks of cancer: The next generation. Cell 144, 646-674 (2011).

29. Wculek, S. K. \& Malanchi, I. Neutrophils support lung colonization of metastasis-initiating breast cancer cells. Nature 528, 413-417 (2015).

30. Chung, W.-J. et al. Kras mutant genetically engineered mouse models of human cancers are genomically heterogeneous. Proc. Natl. Acad. Sci. 114, E10947-E10955 (2017).

31. De Chaisemartin, L. et al. Characterization of chemokines and adhesion molecules associated with $\mathrm{T}$ cell presence in tertiary lymphoid structures in human lung cancer. Cancer Res. 71, 6391-6399 (2011).

32. Helmink, B. A. et al. B cells and tertiary lymphoid structures promote immunotherapy response. Nature 577, 549-555 (2020).

33. Petitprez, F. et al. B cells are associated with survival and immunotherapy response in sarcoma. Nature 577, 556-560 (2020). 
bioRxiv preprint doi: https://doi.org/10.1101/2020.12.22.423126; this version posted December 22, 2020. The copyright holder for this preprint (which was not certified by peer review) is the author/funder, who has granted bioRxiv a license to display the preprint in

de Carné, Boumelha, Law et al.

22 December 2020

34. Cabrita, R. et al. Tertiary lymphoid structures improve immunotherapy and survival in melanoma. Nature 577, 561-565 (2020).

35. Mosely, S. I. S. et al. Rational Selection of Syngeneic Preclinical Tumor Models for Immunotherapeutic Drug Discovery. Cancer Immunol. Res. 5, 2941 (2017).

36. Sotillo, R. et al. Mad2-induced chromosome instability leads to lung tumor relapse after oncogene withdrawal. Nature 464, 436-440 (2010).

37. Mcgranahan, N. et al. Clonal neoantigens elicit T cell immunoreactivity and sensitivity to immune checkpoint blockade. Science (80-. ). 351, 1463-1469 (2016).

38. Wang, S., Jia, M., He, Z. \& Liu, X. S. APOBEC3B and APOBEC mutational signature as potential predictive markers for immunotherapy response in nonsmall cell lung cancer. Oncogene 37, 3924-3936 (2018).

39. Miao, D. et al. Genomic correlates of response to immune checkpoint blockade in microsatellite-stable solid tumors. Nat. Genet. 50, 1271-1281 (2018).

40. Hellmann, M. D. et al. Nivolumab plus ipilimumab in lung cancer with a high tumor mutational burden. N. Engl. J. Med. 378, 2093-2104 (2018).

41. Rizvi, N. A. et al. Mutational landscape determines sensitivity to PD-1 blockade in non-small cell lung cancer. Science (80-. ). 348, 124-128 (2015).

42. Balar, A. V. et al. Atezolizumab as first-line treatment in cisplatin-ineligible patients with locally advanced and metastatic urothelial carcinoma: a singlearm, multicentre, phase 2 trial. Lancet 389, 67-76 (2017).

43. Hong, D. S. et al. KRAS G12C Inhibition with Sotorasib in Advanced Solid Tumors . N. Engl. J. Med. 383, 1207-1217 (2020).

44. Xue, J. Y. et al. Rapid non-uniform adaptation to conformation-specific KRAS(G12C) inhibition. Nature 577, 421-425 (2020).

45. DuPage, M., Dooley, A. L. \& Jacks, T. Conditional mouse lung cancer models using adenoviral or lentiviral delivery of Cre recombinase. Nat. Protoc. 4 , 1064-1072 (2009).

46. Brown, W. L. et al. A rabbit monoclonal antibody against the antiviral and cancer genomic DNA mutating enzyme APOBEC3B. Antibodies (Basel) 8, (2019).

47. Li, H. \& Durbin, R. Fast and accurate short read alignment with BurrowsWheeler transform. Bioinformatics 25, 1754-1760 (2009).

48. $\mathrm{Li}, \mathrm{H}$. et al. The Sequence Alignment/Map format and SAMtools. Bioinformatics 25, 2078-2079 (2009).

49. Van der Auwera, G. A. et al. From FastQ data to high confidence variant calls: the Genome Analysis Toolkit best practices pipeline. Curr. Protoc. Bioinforma. 11, 1-11 (2014).

50. Talevich, E., Shain, A. H., Botton, T. \& Bastian, B. C. CNVkit: Genome-Wide Copy Number Detection and Visualization from Targeted DNA Sequencing. PLoS Comput. Biol. 12, 1-18 (2016).

51. Turajlic, S. et al. Deterministic Evolutionary Trajectories Influence Primary 
bioRxiv preprint doi: https://doi.org/10.1101/2020.12.22.423126; this version posted December 22, 2020. The copyright holder for this preprint (which was not certified by peer review) is the author/funder, who has granted bioRxiv a license to display the preprint in perpetuity. It is made available under aCC-BY 4.0 International license.

de Carné, Boumelha, Law et al.

22 December 2020

Tumor Growth: TRACERx Renal. Cell 173, 595-610 (2018).

52. Pfaffl, M. W. A new mathematical model for relative quantification in real-time RT-PCR. Nucleic Acids Res. 29, 2002-2007 (2001). 


\section{Figure legends}

Figure 1. The KP mouse model of lung adenocarcinoma is not immunogenic

(A) Waterfall plot of tumour volume change over two weeks in $\mathrm{KP} ; \operatorname{Rag}^{+/-}(\mathrm{n}=5)$ and $\mathrm{KP} ;$ Rag $^{-/-}$mice $(\mathrm{n}=4) 12$ weeks after tumour initiation. Unpaired, two-tailed Student's t-test; ns, not significant.

(B) Representative immunohistochemistry staining for CD4 and CD8 in lung tumours from KP mice. Scale bar represents $100 \mu \mathrm{m}$.

(C) Schematic of KP tumour induction and treatment schedule. Cre-expressing adenovirus (AdCre, $1 \times 10^{6} \mathrm{pfu}$ ) was delivered intratracheally and mice were regularly scanned by micro-CT. 12 weeks after tumour initiation, tumour-bearing mice were treated three times ( $\mathrm{d} 0, \mathrm{~d} 4$ and $\mathrm{d} 8$ ) intraperitoneally with $10 \mathrm{mg} / \mathrm{kg}$ anti-PD-L1 and 5 $\mathrm{mg} / \mathrm{kg}$ anti-CTLA-4 or corresponding isotype control (IgG Ctl). Tumour growth and survival were monitored until the experimental endpoints.

(D) Waterfall plot of tumour volume change in KP-tumour-bearing mice treated as in

(C) Mice were scanned 2 weeks after the pre-treatment scan, IgG Ctl $(n=7)$ and antiPD-L1 + anti-CTLA-4 ( $n=7)$. Unpaired, two-tailed Student's t-test; n.s, not significant.

(E) Representative micro-CT scans of mice treated as in (C). Red arrows indicate tumours.

(F) Kaplan-Meier survival analysis of KP-tumour-bearing mouse survival treated as in (C), IgG Ctl ( $n=7)$ and anti-PD-L1 + anti-CTLA-4 ( $n=7)$. Log-rank (Mantel-Cox) test; n.s, not significant.

Figure 2. Effect of APOBEC3B expression in KP tumours and urethaneinduced tumours.

(A) Expression level of genes carrying APOBEC non-synonymous mutations in the TCGA LUAD compared with genes with other non-synonymous mutations. Linear model, $\mathrm{P}<0.0001$.

(B) Immunohistochemistry of human APOBEC3B in lung tumours from KP and KPA mice. Scale bar represents $200 \mu \mathrm{m}$.

(C) Expression of APOBEC3B by qPCR in KP, KPA and KPAR tumours. Relative expression is normalised on the mean expression of Sdha, Tbp and Hsp90ab1. Mean expression, SEM and individual p-value. The $p$-value is indicated only when 
significant, One-way ANOVA, FDR 0.05 (ns $P>0.05,{ }^{*} \mathrm{P} \leq 0.05,{ }^{* *} \mathrm{P} \leq 0.01,{ }^{* *} \mathrm{P} \leq 0.001$, **** $\mathrm{P} \geq 0.0001)$.

(D) Number of tumours per mouse per model in KPA ( $\mathrm{n}=5$ mice) and KPAR ( $\mathrm{n}=3$ mice) mice estimated from micro-CT scans.

(E) Mean of tumour volume over time per model in KPA ( $n=5$ mice) and KPAR $(n=3$ mice) mice estimated from micro-CT scans.

(F) Waterfall plot of KP and KPA tumour volume change on treatment with ICB. KP $(n=4)$ and KPA-tumour-bearing $(n=7)$ mice were scanned and treated four times $(d 0$, d3, d7 and d10) with $200 \mu \mathrm{g}$ of anti-PD-1 and $200 \mu \mathrm{g}$ of anti-CTLA-4, mice were scanned 2 weeks after the pre-treatment scan. One-way ANOVA, ns = non-significant. (G) Immunohistochemistry of lung tumours from KPA mice. CD4 and CD8 immunostaining of helper and cytotoxic T cells, respectively. Scale bar represents 200 $\mu \mathrm{m}$.

(H) mRNA expression by qPCR of markers of immune cells in KP ( $n=5$ mice) and KPA ( $n=4$ mice) tumours and adjacent lung tissue. Relative expression is normalised on the mean expression of Sdha, Tbp and Hsp90ab1. Mean expression, SEM and individual $p$-value. The $p$-value is indicated only when significant, One-way ANOVA, FDR 0.05 (ns $P>0.05,{ }^{*} \mathrm{P} \leq 0.05,{ }^{* *} \mathrm{P} \leq 0.01,{ }^{* * *} \mathrm{P} \leq 0.001,{ }^{* * * *} \mathrm{P} \geq 0.0001$ ).

(I) Mean exonic SNVs per models estimated per whole-exome sequencing broken down into clonal and subclonal.

\section{Figure 3. APOBEC3B expression does not induce immunogenicity of}

\section{autochthonous lung tumours.}

(A) Expression of $A 3 B i$ by qPCR in normal lungs ( $\mathrm{Ctl}$ ), adjacent to tumour lung tissue (Tam and AdCre) and tumours from A3Bi-CreER and A3Bi-AdCre models. Tumour formation was induced by urethane. Relative expression is normalised on the mean expression of Sdha, Tbp and Actb. Mean expression, SEM and individual $p$-value. The p-value is indicated only when significant, One-way ANOVA, FDR 0.05 (ns P>0.05, * $\left.P \leq 0.05,{ }^{* *} P \leq 0.01,{ }^{* *} P \leq 0.001,{ }^{* * * *} P \geq 0.0001\right)$.

(B) Expression of $A 3 B i$ by qPCR in paired normal-adjacent tissue and tumour of UrA3Bi-CreER ( $n=12$ tumours from 4 mice, squares) and UrA3Bi-AdCre $(n=7$ tumours from 4 mice, circles), each symbol represents one tumour or adjacent tissue. Relative expression is normalised on the mean expression of Sdha, Tbp and Actb. Two-tailed paired t-test (ns $\mathrm{P}>0.05,{ }^{*} \mathrm{P} \leq 0.05$, ${ }^{* *} \mathrm{P} \leq 0.01$, ${ }^{* *} \mathrm{P} \leq 0.001$, ${ }^{* * *} \mathrm{P} \geq 0.0001$ ). 
(C) Immunohistochemistry of human APOBEC3B in lung tumours from urethane (Ur) and UrA3Bi-CreER (UrA3Bi-CreER) models. Scale bar represents $200 \mu \mathrm{m}$.

(D) Proportion of tumour grades evaluated from H\&E staining of tumour-bearing lungs in Ur ( $\mathrm{n}=8$ mice) and UrA3Bi-CreER ( $\mathrm{n}=8$ mice) models. Contingency analysis, Chisquare test (ns $P>0.05,{ }^{*} P \leq 0.05,{ }^{* *} P \leq 0.01,{ }^{* *} P \leq 0.001,{ }^{* * *} P \geq 0.0001$ ).

(E) Percentage of necrosis evaluated from $\mathrm{H} \& \mathrm{E}$ staining of tumour-bearing lungs in Ur ( $n=8$ mice) and UrA3Bi-CreER ( $n=8$ mice) models. Two-tailed unpaired Mann Whitney test (ns $P>0.05,{ }^{*} \mathrm{P} \leq 0.05,{ }^{* *} \mathrm{P} \leq 0.01,{ }^{* *} \mathrm{P} \leq 0.001,{ }^{* * *} \mathrm{P} \geq 0.0001$ ).

(F) Mean exonic SNVs per models estimated per whole-exome sequencing and broken down into clonal and subclonal.

(G-H) FACS analysis of subpopulations of $\mathrm{Cd}^{+} \mathrm{T}$ cells $(\mathrm{G})$ and $\mathrm{Cd} 4^{+}$cells $(\mathrm{H})$ in UrA3Bi-CreER and Ur tumours. Tumour-free lungs are used as a control for comparison. Coloured dots represent individual mice from two independent experiments. Mean percentage of indicated cells, SEM and individual p-value of 6 tumour-free lungs and 13 pools of tumours from UrA3Bi (CreER), Kruskal-Wallis test (ns $P>0.05,{ }^{*} P \leq 0.05,{ }^{* *} P \leq 0.01,{ }^{* * *} P \leq 0.001,{ }^{* * *} P \geq 0.0001$ ).

(I) Waterfall plot of tumour volume change in UrA3Bi-CreER mice. Tumour-bearing mice were scanned and treated four times (d0, d3, d7 and d10) with $200 \mu \mathrm{g}$ of antiPD-1 and $200 \mu \mathrm{g}$ of anti-CTLA-4 ( $n=2$ mice) or corresponding isotype control $(n=2$ mice), mice were scanned 2 weeks after the pre-treatment scan. Two-way ANOVA, ns $=$ non-significant.

\section{Figure 4. Generation of a novel immunogenic cell line KPAR1.3}

(A) Growth of KPAR1.1 and KPAR1.3 cells transplanted subcutaneously into

syngeneic WT and Rag1/- mice. Data are mean tumour volumes \pm SEM, $n=6$ mice per group. Two-way ANOVA, n.s, not significant; *, P $\leq 0.05$.

(B) Frequency of clonal exonic mutations in an autochthonous KPAR tumour, the KPAR parental cell line and the KPAR1.1 and KPAR1.3 single-cell clones, estimated per whole-exome sequencing.

(C) Frequency of clonal predicted neoantigens identified using NetMHC4.0, in an autochthonous KPAR tumour, the KPAR parental cell line and the KPAR1.1 and KPAR1.3 single-cell clones. Peptides with a rank threshold of $<2$ or $<0.5$ were designated as weak or strong MHC-I binders, respectively. 
bioRxiv preprint doi: https://doi.org/10.1101/2020.12.22.423126; this version posted December 22, 2020. The copyright holder for this preprint (which was not certified by peer review) is the author/funder, who has granted bioRxiv a license to display the preprint in perpetuity. It is made available under aCC-BY 4.0 International license.

de Carné, Boumelha, Law et al.

22 December 2020

(D) mRNA expression by qPCR of APOBEC3B in autochthonous KPAR tumours, KPAR parental cells, KPAR1.1 cells and KPAR1.3 cells. All values are normalised to the mean expression of Sdha, Tbp and Hsp90ab1.

(E) Representative image of APOBEC3B immunohistochemistry staining in orthotopic KPAR1.3 tumours. Scale bar represents $100 \mu \mathrm{m}$.

\section{Figure 5. Subcutaneous and orthotopic KPAR1.3 tumours are responsive to} ICB

(A) Growth of KPAR1.3 subcutaneous tumours from mice treated intraperitoneally with $200 \mu \mathrm{g}$ anti-PD-1 and/or 200 $\mu \mathrm{g}$ anti-CTLA-4 or corresponding isotype control (lgG Ctl) on day 10,14, 17 and 21. Data are mean tumour volumes $\pm S E M, n=6$ mice per group. Two-way ANOVA; ${ }^{* *} \mathrm{P} \leq 0.01,{ }^{* * *} \mathrm{P} \leq 0.001$.

(B) Kaplan-Meier survival of mice from (A). The black arrow indicates the time at which mice that previously rejected the primary tumour were re-challenged on the opposite flank. Log-rank (Mantel-Cox) test; ${ }^{* *} \mathrm{P} \leq 0.01$.

(C and D) Flow cytometry analysis of the frequency of Foxp3 ${ }^{+}$Tregs (C), effector memory (CD44 $\left.{ }^{+} \mathrm{CD} 62 \mathrm{~L}^{-}\right) \mathrm{CD}^{+} \mathrm{T}$ cells $\left(\mathrm{D}\right.$, left) and PD-1+ $\mathrm{CD} 8^{+} \mathrm{T}$ cells $(\mathrm{D}$, right) in subcutaneous tumours after treatment as in (A). Treatment was on day 10,14 and 17 and mice were culled on day 18. Data are mean \pm SEM, $n=5$ mice per group. Oneway ANOVA, FDR 0.05; ** P $\leq 0.01,{ }^{* * *} \mathrm{P} \leq 0.001$.

(E) Kaplan-Meier survival of mice treated intraperitoneally with $200 \mu \mathrm{g}$ anti-PD-1 and/or $200 \mu \mathrm{g}$ anti-CTLA-4 or corresponding isotype control (IgG Ctl) after orthotopic transplantation of KPAR1.3 cells. Treatment was initiated once tumours were detectable by micro-CT and were administered twice weekly for a maximum of 3 weeks. IgG Ctl ( $n=6)$, anti-PD1 $(n=6)$, anti-CTLA4 $(n=6)$ and anti-PD-1 + anti-CTLA-4 $(n=7)$. Log-rank (Mantel-Cox) test; * $P \leq 0.05,{ }^{* *} \mathrm{P} \leq 0.01$.

(F and G) Quantification of immunohistochemistry staining for CD8 (F) and Foxp3 (G) in orthotopic KPAR1.3 lung tumours after treatment as in (E). Data are mean (large symbols) \pm SEM, $n=3$ mice per group, small symbols represent individual tumours. One-way ANOVA, FDR 0.05; ns, not significant, ${ }^{*} \mathrm{P} \leq 0.05,{ }^{* *} \mathrm{P} \leq 0.01$.

Figure 6. KPAR1.3 orthotopic tumours generate an adaptive immune response (A) Immune profile of KPAR1.3 and KPB6 orthotopic tumours compared to normal lung, assessed by flow cytometry. 
(B) Frequency of tumour-infiltrating $\mathrm{T}$ cell populations and NK cells (CD11 bCD49b+Nkp46+).

(C) Percentage of naive (CD44-CD62 $\left.\mathrm{L}^{+}\right)$, central memory $\left(\mathrm{CD} 44^{+} \mathrm{CD} 62 \mathrm{~L}^{+}\right)$and effector memory (CD44 $\left.{ }^{+} \mathrm{CD} 62 \mathrm{~L}^{-}\right) \mathrm{CD}^{+}$(left) and CD4 ${ }^{+}$(right) T cells.

(D) Quantification of PD-1, LAG-3 and TIM-3 expression on CD8 ${ }^{+}$(left) and CD4+ (right) T cells.

(E) Representative plot of PD-1 and LAG-3 expression on CD8 ${ }^{+} \mathrm{T}$ cells.

(F) Frequency of $\mathrm{PDL}^{+}$macrophages $\left(\mathrm{CD} 11 \mathrm{~b}^{+} \mathrm{MHCll}^{+} \mathrm{CD} 64^{+}\right), \quad \mathrm{CDC} 2$ $\left(\mathrm{CD} 11 \mathrm{~b}^{+} \mathrm{MHClI}^{+} \mathrm{CD} 24^{+}\right), \quad \mathrm{cDC} 1 \quad\left(\mathrm{CD} 11 \mathrm{c}^{+} \mathrm{CD} 64^{-} \mathrm{CD} 24^{+} \mathrm{CD}^{+} 3^{+}\right), \quad$ monocytes $\left(\mathrm{CD} 11 \mathrm{~b}^{+} \mathrm{Ly}_{6 \mathrm{C}^{+}}\right)$and neutrophils $\left(\mathrm{CD} 11 \mathrm{~b}^{+} \mathrm{Ly} \mathrm{G}^{+}\right)$.

(G) Representative image of tertiary lymphoid structures (TLS) in KPAR1.3 tumourbearing lungs identified by immunohistochemistry staining for B220. Scale bar represents $100 \mu \mathrm{m}$.

In (A)-(D) and (F), data are mean \pm SEM, $n=4$ mice (KPB6) or 9 mice (KPAR1.3), symbols represent pooled tumours from individual mice. In $(A)-(G)$ tumours were analysed 21 days after transplantation. Unpaired, two-tailed Student's t-test; ns, not significant, ${ }^{*} \mathrm{P} \leq 0.05,{ }^{* *} \mathrm{P} \leq 0.01,{ }^{* *} \mathrm{P} \leq 0.001,{ }^{* * * *} \mathrm{P} \leq 0.0001$.

Figure 7. The efficacy of KRAS-G12C inhibition in vivo is greater in immunecompetent mice

(A and $B$ ) Mean \pm SEM $(A)$ and individual $(B)$ KPAR1.3 ${ }^{\mathrm{G} 12 \mathrm{C}}$ tumour volumes in WT and Rag1/- mice treated with vehicle (10\% Pluronic-F127) or AZ-8037 (100 mg/kg daily oral gavage). $n=6$ mice per group. Two-way ANOVA; ${ }^{* *} P \leq 0.001,{ }^{* * *} P \leq 0.0001$.

$(C$ and $D)$ Mean \pm SEM (C) and individual (D) KPB6 ${ }^{\mathrm{G} 12 \mathrm{C}}$ tumour volumes in WT and $R_{\text {ag }}{ }^{-/}$mice treated as in (C). $\mathrm{n}=6$ mice per group.

(E) Heatmap showing mRNA expression from qPCR of KPAR1.3 ${ }^{\mathrm{G} 12 \mathrm{C}}$ tumours treated for 7 days with $100 \mathrm{mg} / \mathrm{kg}$ AZ-8037. Gene expression is scaled across all tumours. Only genes with a significant mean difference between AZ-8037 and vehicle groups (one-way ANOVA, FDR<0.05) are shown. 
bioRxiv preprint doi: https://doi.org/10.1101/2020.12.22.423126; this version posted December 22, 2020. The copyright holder for this preprint (which was not certified by peer review) is the author/funder, who has granted bioRxiv a license to display the preprint in perpetuity. It is made available under aCC-BY 4.0 International license.

\section{Figure 1}

A

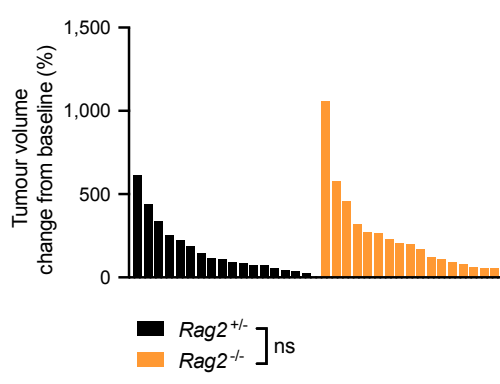

D

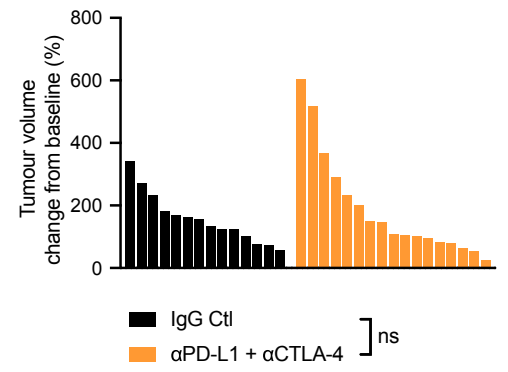

B

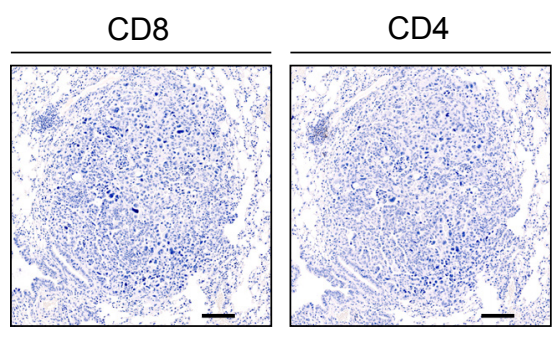

E

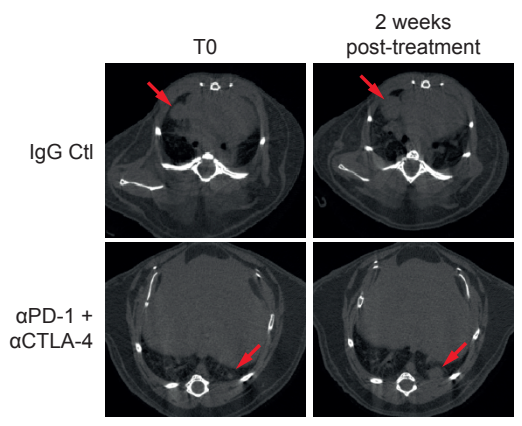

C

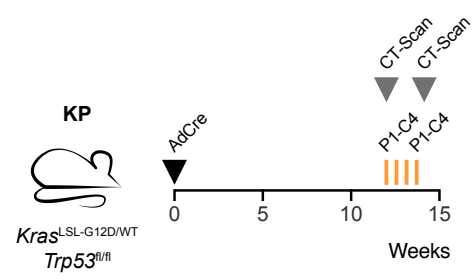

$\mathbf{F}$

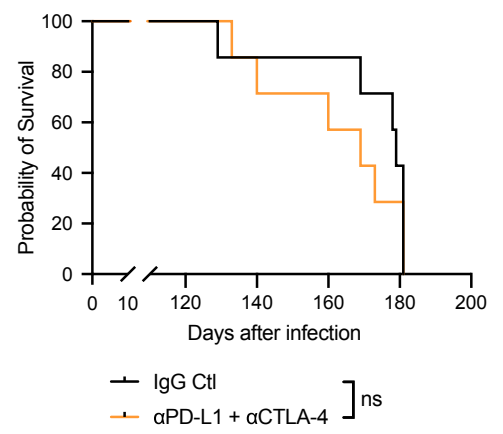


bioRxiv preprint doi: https://doi.org/10.1101/2020.12.22.423126; this version posted December 22, 2020. The copyright holder for this preprint (which was not certified by peer review) is the author/funder, who has granted bioRxiv a license to display the preprint in perpetuity. It is made available under aCC-BY 4.0 International license.

\section{Figure 2}

A

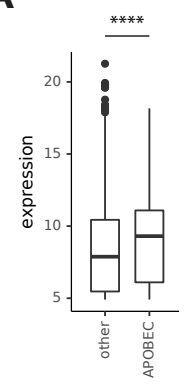

B

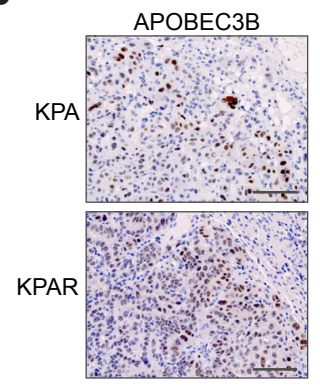

C

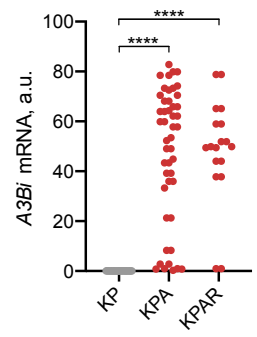

D

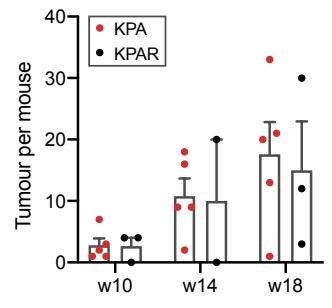

E

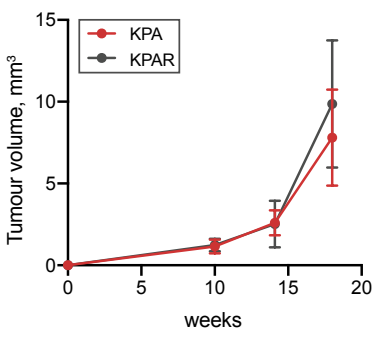

$\mathbf{F}$

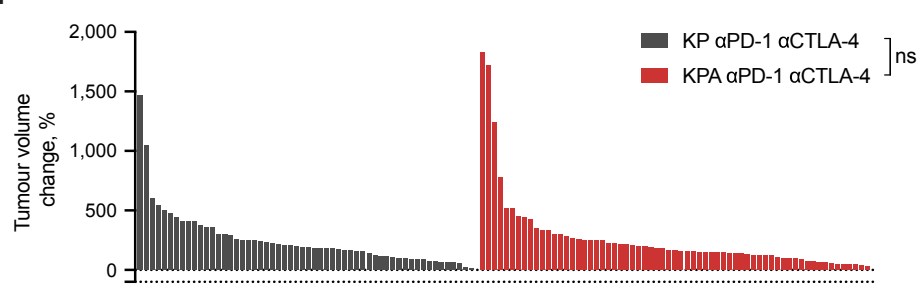

G

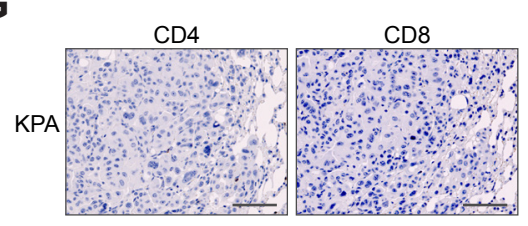

H

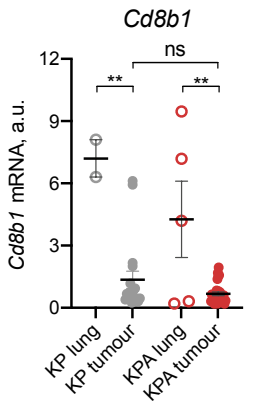

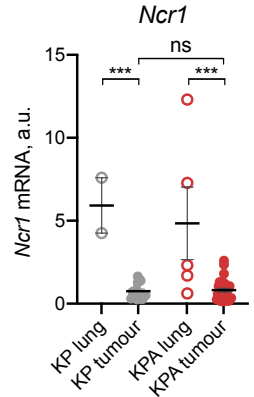

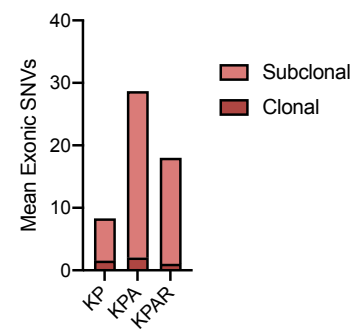


bioRxiv preprint doi: https://doi.org/10.1101/2020.12.22.423126; this version posted December 22, 2020. The copyright holder for this preprint (which was not certified by peer review) is the author/funder, who has granted bioRxiv a license to display the preprint in perpetuity. It is made available under aCC-BY 4.0 International license.

\section{Figure 3}

A

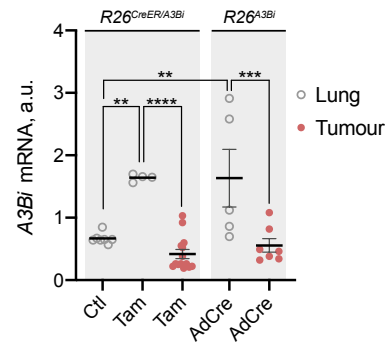

B

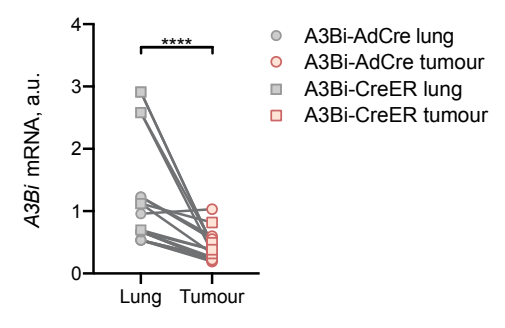

C

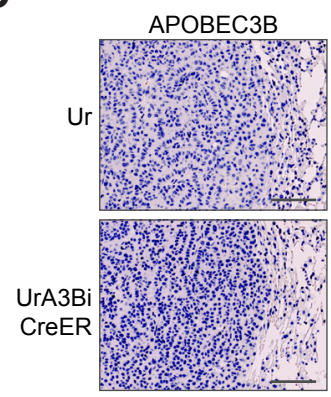

D

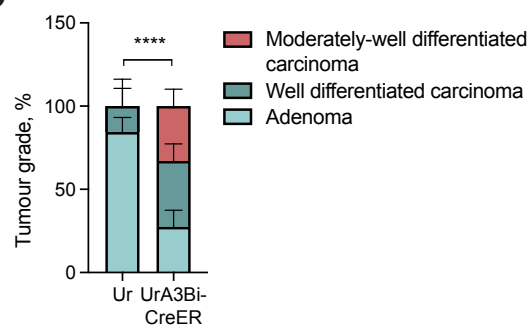

$\mathbf{E}$

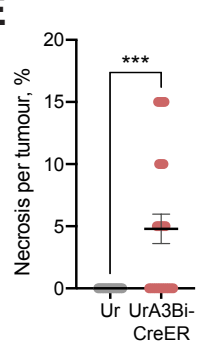

$\mathbf{F}$

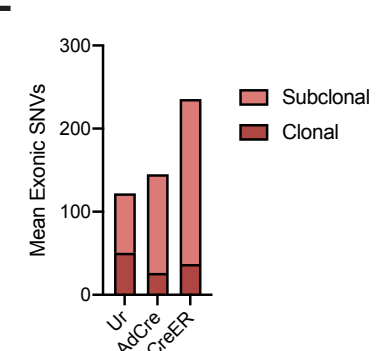

G

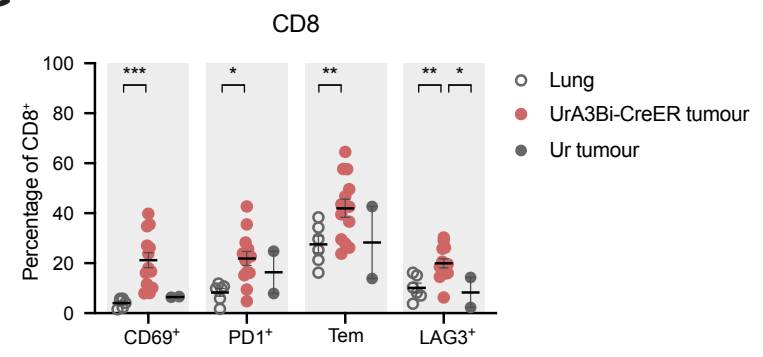

I

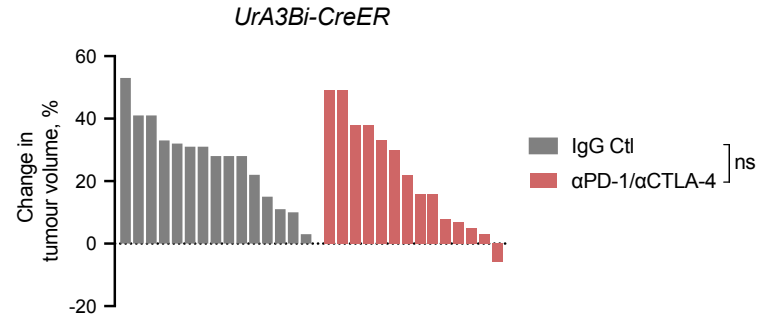

H

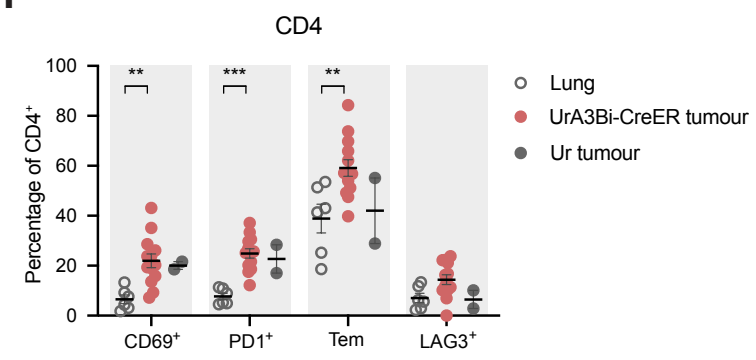


bioRxiv preprint doi: https://doi.org/10.1101/2020.12.22.423126; this version posted December 22, 2020. The copyright holder for this preprint (which was not certified by peer review) is the author/funder, who has granted bioRxiv a license to display the preprint in perpetuity. It is made available under aCC-BY 4.0 International license.

\section{Figure 4}

A

KPAR1.1

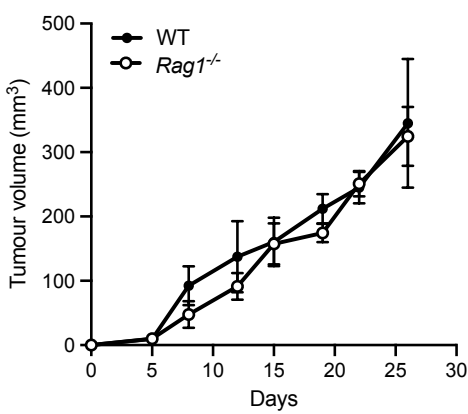

C

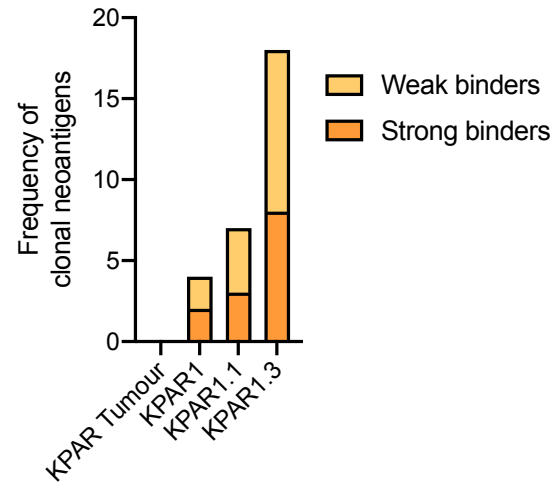

B
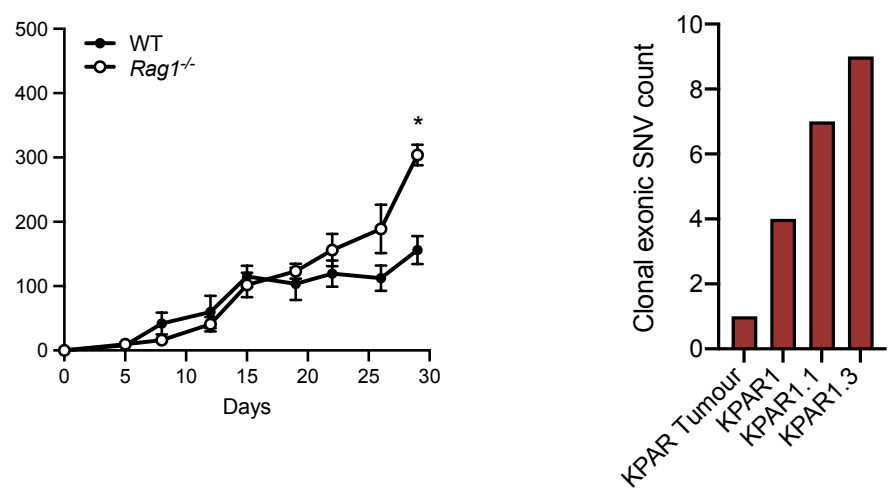

$\mathbf{E}$

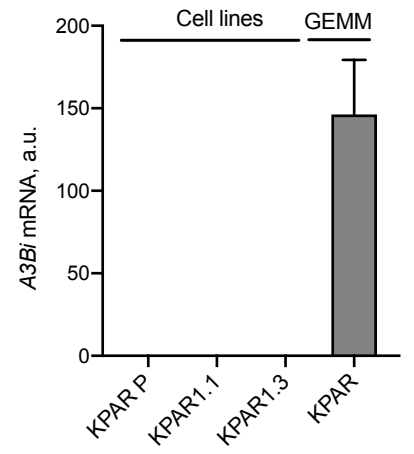

APOBEC3B

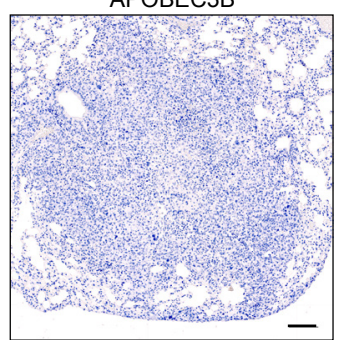


bioRxiv preprint dol: https://doi.org/10.1101/2020.12.22.423126; this version posted December 22, 2020. The copyright holder for this preprint (which was not certified by peer review) is the author/funder, who has granted bioRxiv a license to display the preprint in perpetuity. It is made available under aCC-BY 4.0 International license.

Figure 5

A

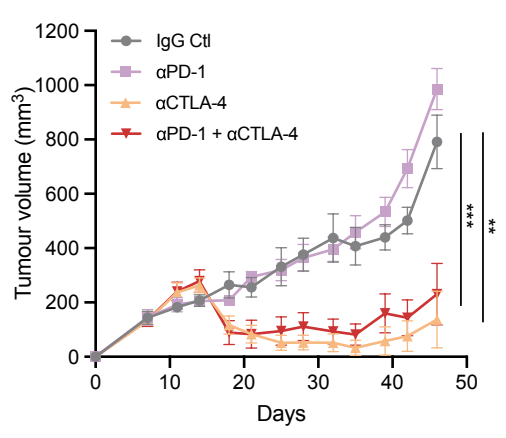

D

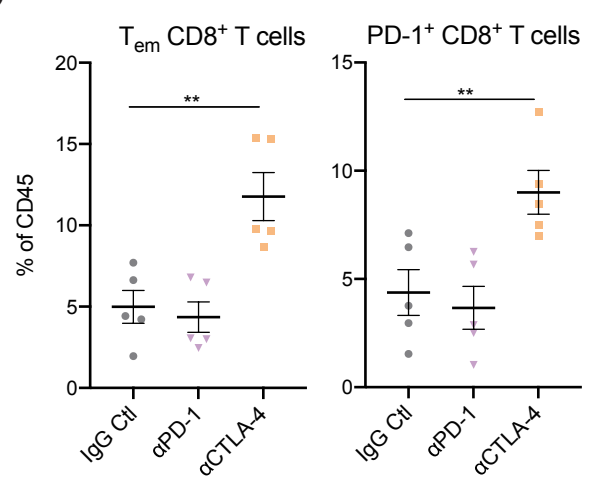

F

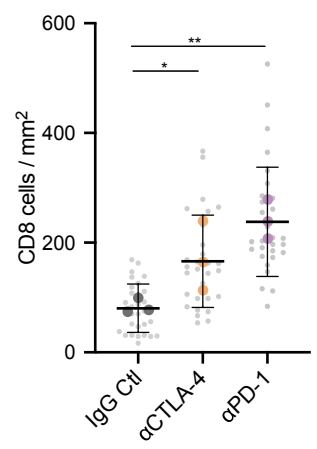

G

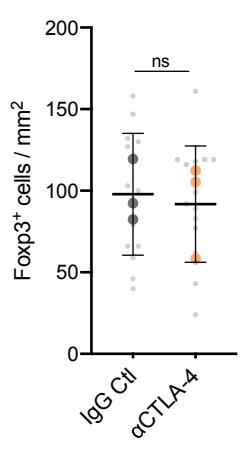

B

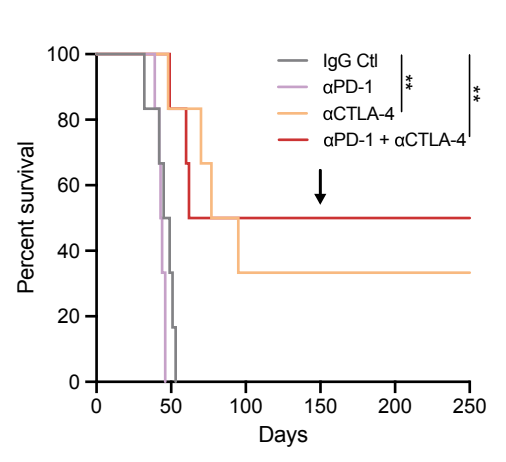

C

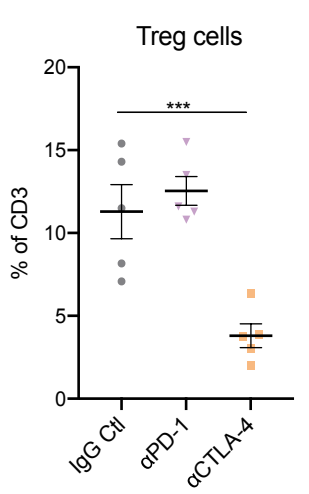

E

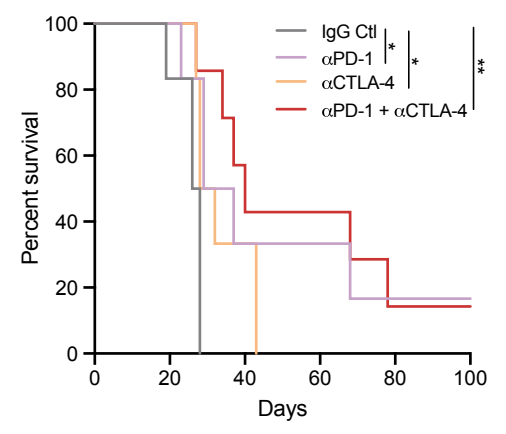


bioRxiv preprint doi: https://doi.org/10.1101/2020.12.22.423126; this version posted December 22, 2020. The copyright holder for this preprint (which was not certified by peer review) is the author/funder, who has granted bioRxiv a license to display the preprint in perpetuity. It is made available under aCC-BY 4.0 International license.

\section{Figure 6}

A

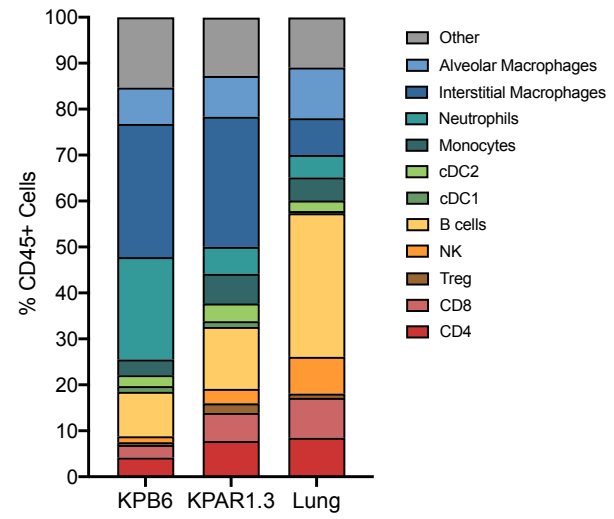

C
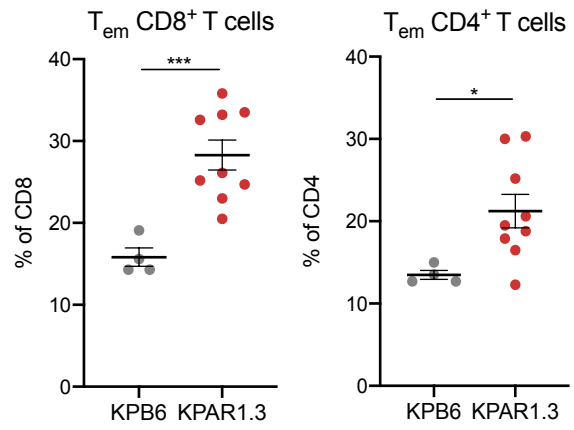

E

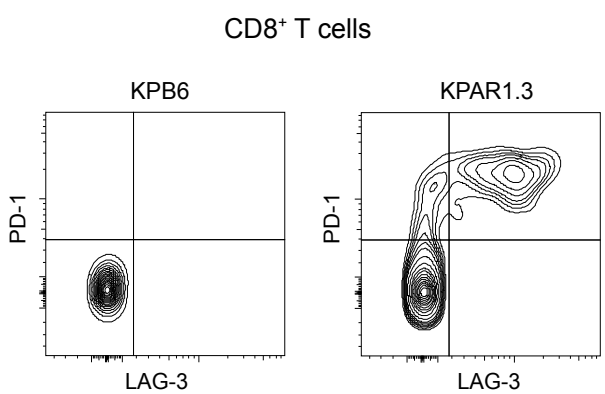

G

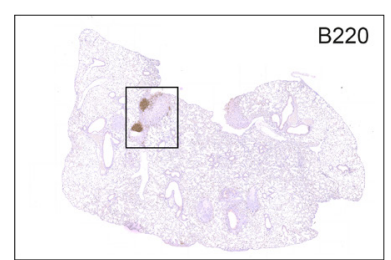

B

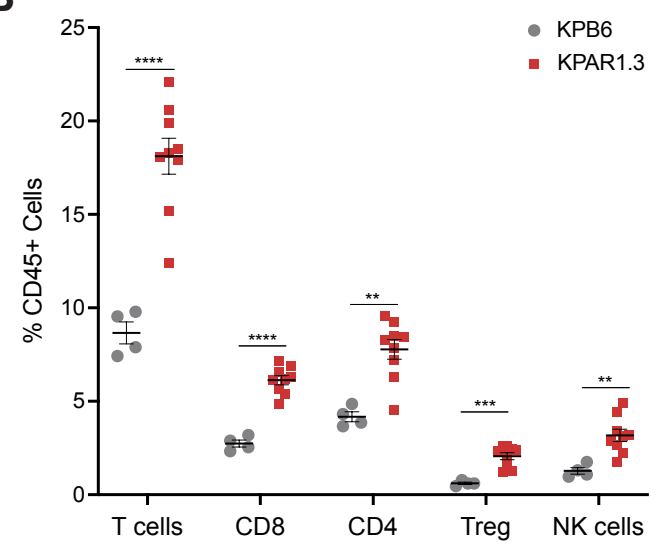

D
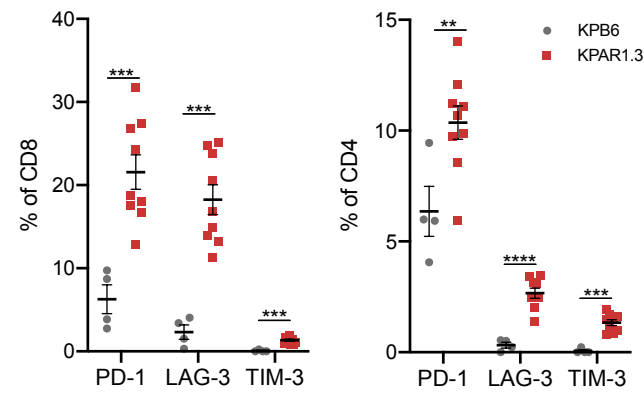

F
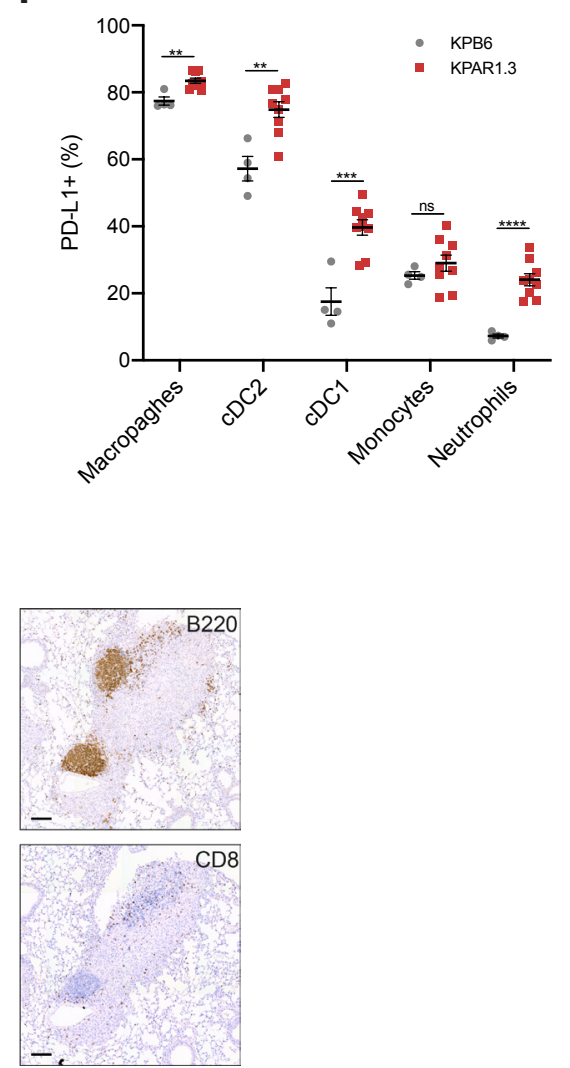
bioRxiv preprint doi: https://doi.org/10.1101/2020.12.22.423126; this version posted December 22, 2020. The copyright holder for this preprint (which was not certified by peer review) is the author/funder, who has granted bioRxiv a license to display the preprint in perpetuity. It is made available under aCC-BY 4.0 International license.

\section{Figure 7}

A

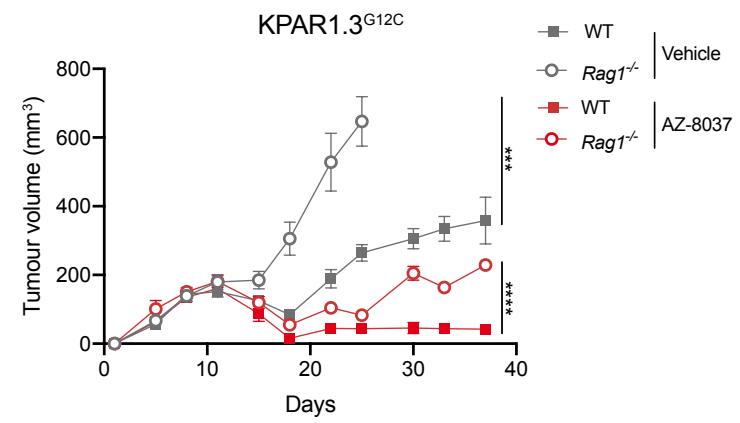

B

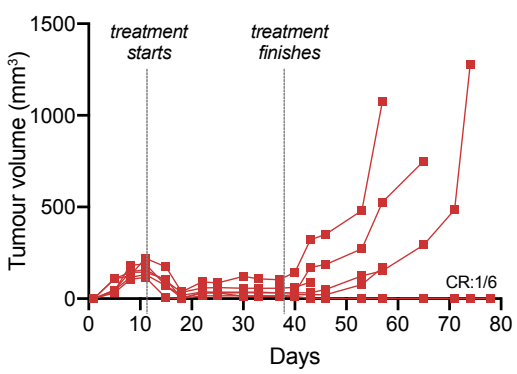

E

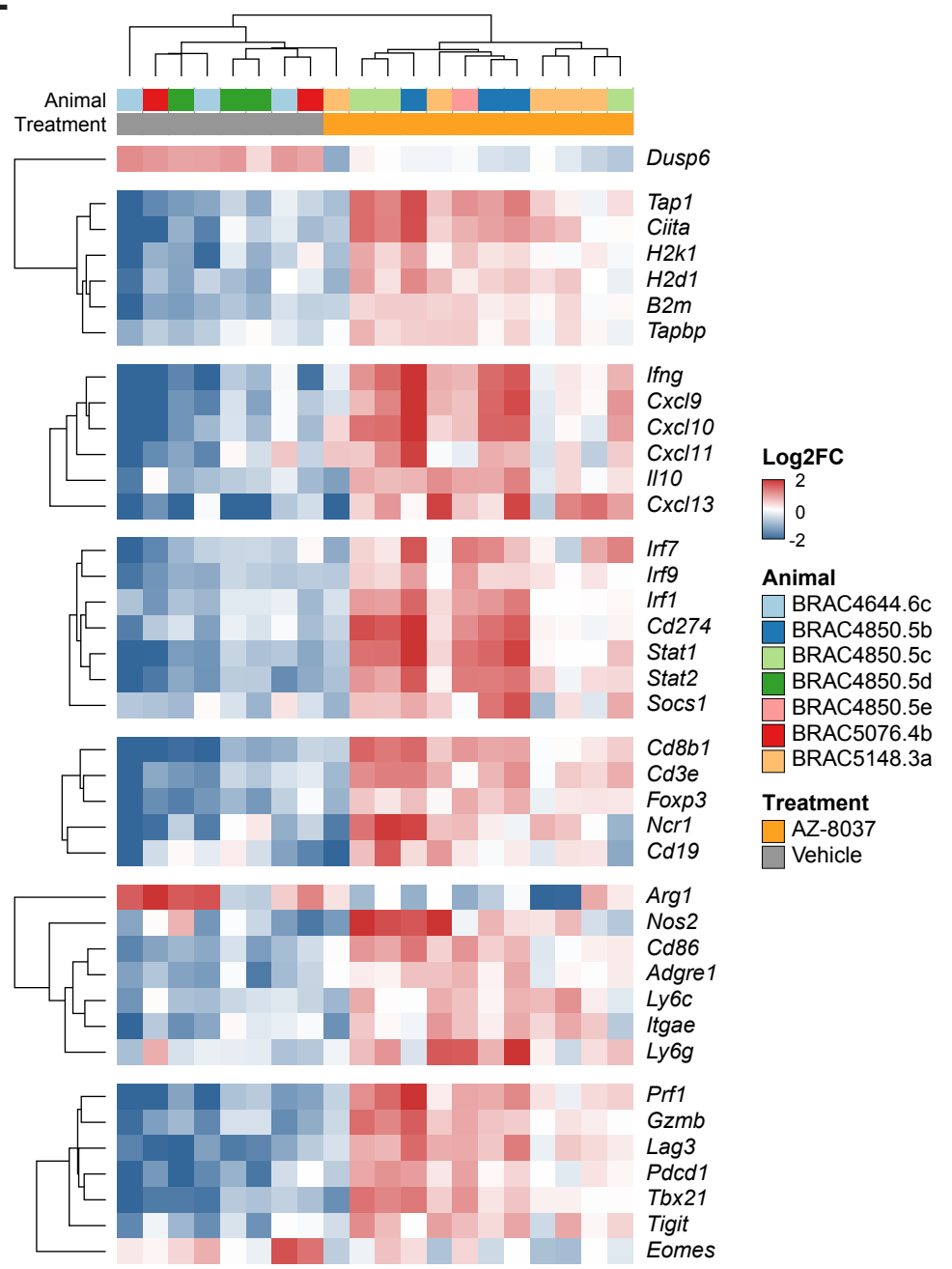

C

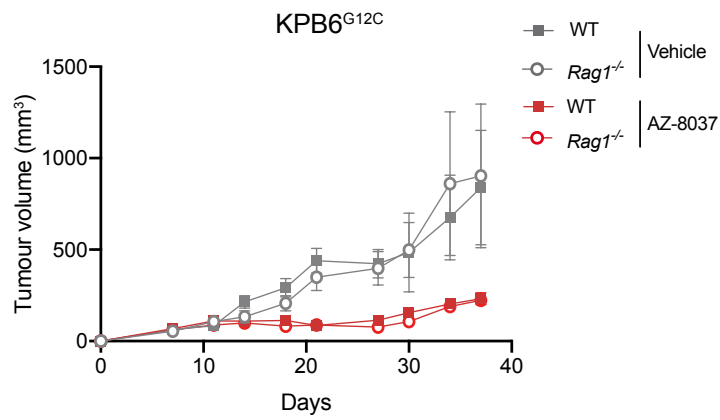

D

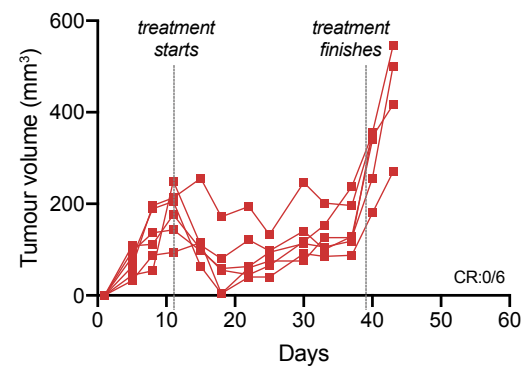

